Article

\title{
Biomolecules, Fatty Acids, Meat Quality, and Growth Performance of Slow-Growing Chickens in an Organic Raising System
}

\author{
Wittawat Molee ${ }^{1, *(\mathbb{D})}$, Wichuta Khosinklang ${ }^{1}\left(\mathbb{D}\right.$, Pramkamon Tongduang ${ }^{1}\left(\mathbb{D}\right.$, Kanjana Thumanu ${ }^{2}$, \\ Jirawat Yongsawatdigul $^{3} \mathbb{D}$ and Amonrat Molee ${ }^{1}$
}

check for updates

Citation: Molee, W.; Khosinklang, W.; Tongduang, P.; Thumanu, K.; Yongsawatdigul, J.; Molee, A. Biomolecules, Fatty Acids, Meat Quality, and Growth Performance of Slow-Growing Chickens in an Organic Raising System. Animals 2022, 12, 570. https://doi.org/ 10.3390/ani12050570

Academic Editors: Francesca Soglia and Simona Mattioli

Received: 5 January 2022

Accepted: 21 February 2022

Published: 24 February 2022

Publisher's Note: MDPI stays neutral with regard to jurisdictional claims in published maps and institutional affiliations.

Copyright: (C) 2022 by the authors. Licensee MDPI, Basel, Switzerland. This article is an open access article distributed under the terms and conditions of the Creative Commons Attribution (CC BY) license (https:// creativecommons.org/licenses/by/ $4.0 /)$.
1 School of Animal Technology and Innovation, Institute of Agricultural Technology, Suranaree University of Technology, Nakhon Ratchasima 30000, Thailand; wichutaploy085411@gmail.com (W.K.); woonwoon.kati@gmail.com (P.T.); amonrat@sut.ac.th (A.M.)

2 Research and Facility Department, Synchrotron Light Research Institute (Public Organization), Nakhon Ratchasima 30000, Thailand; kthumanu@gmail.com

3 School of Food Technology, Institute of Agricultural Technology, Suranaree University of Technology, Nakhon Ratchasima 30000, Thailand; jirawat@sut.ac.th

* Correspondence: wittawat@sut.ac.th; Tel.: +66-8-9920-4970

Simple Summary: The increasing demand for nutritionally rich quality products by health-conscious consumers has raised the need to explore alternative farming systems such as organic farming. In this study, we report the efficiency of Korat chickens grown in organic farm conditions. The study demonstrates not only that the slow-growing Korat chicken is suitable for organic farming, but also that the organic raising system improves its growth performance and meat quality. Furthermore, the study unveils a set of biochemical traits using synchrotron radiation-based Fourier transform infrared that show significant differences between the meat quality of chickens raised under conventional and organic raising systems, suggesting their potential use as markers to monitor the meat quality. The findings of this study provide evidence for the potential of organic raising systems for commercial adoption in tropical areas such as Southeast Asia.

Abstract: This study was to determine the effect of the organic raising system (OR) on growth performance, meat quality, and physicochemical properties of slow-growing chickens. Three hundred and sixty (one-day-old) Korat chickens (KRC) were randomly assigned to control (CO) and OR groups. The groups comprised six replicates of thirty chickens each. The chickens were housed in indoor pens ( 5 birds $/ \mathrm{m}^{2}$ ), wherein those in OR had free access to Ruzi pasture ( $\left.1 \mathrm{bird} / 4 \mathrm{~m}^{2}\right)$ from $\mathrm{d}$ 21 to $\mathrm{d} 84$ of age. In the $\mathrm{CO}$ group, chickens were fed with a mixed feed derived from commercial feedstuffs, while those in the OR group were fed with mixed feed derived from organic feedstuffs. The results revealed a lower feed intake $(p<0.0001)$ and feed conversion ratio $(p=0.004)$ in the OR. The OR increased total collagen, protein, shear force, color of skin and meat, and decreased abdominal fat $(p<0.05)$. The OR improved fatty acid with increased DHA, n-3 PUFA, and decreased the ratio of $\mathrm{n}-6$ to n-3 PUFA in KRC meat $(p<0.05)$. The synchrotron radiation-based Fourier transform infrared spectroscopy and correlation loading analyses confirmed these results. In conclusion, our results proved that OR could improve growth performance and meat quality and suggested the raising system be adopted commercially. In addition, the observed differences in biochemical molecules could also serve as markers for monitoring meat quality.

Keywords: organic raising system; meat quality; omega-3 fatty acid; slow-growing chicken; synchrotron FTIR

\section{Introduction}

Raising systems have become a more serious issue, particularly in terms of animal welfare [1]. The strategies to increase the production rate to meet the growing demand for 
chicken meat have led to unintentional negative effects such as muscle abnormalities and increased susceptibility to stress-induced myopathy in chickens [2]. However, the increasing health consciousness amongst consumers has increased the interest in environmentally friendly animal products produced on natural or organic farms.

The organic raising system (OR) is a poultry management system where the birds are fed only with organic feed (produced without chemical fertilizers and pesticides) and allowed to grow and express their natural behaviors without the use of chemicals such as antibiotics and other drugs [3]. All ORs are free-range systems, as they allow free outdoor access; however, the reverse is not true, as the free-range systems that are not OR use general feed, medications, and chemicals [4]. The OR has gained increasing interest worldwide because it is environmentally friendly, its products are free from chemical residues, and it follows a high standard for the welfare of birds [3]. Chickens raised in OR have a high nutritional value in terms of protein, total collagen, and total omega-3 polyunsaturated fatty acid (n-3 PUFA) contents in meat [1,5-7]. However, the breeds suitable for OR need to be tolerant, resilient, adaptable, capable of utilizing quality balanced feed [8-10], and incur a low cost of production. Therefore, not all breeds are adaptable, but the slow-growing chickens seem to be suitable for the OR. The Korat chicken (KRC) is one such slow-growing chicken with an average daily gain (ADG) of 19.8 to $21.0 \mathrm{~g} / \mathrm{d}$, and it takes about $70 \mathrm{~d}$ to reach the marketable body weight $(\mathrm{BW})$ of $\sim 1.2 \mathrm{~kg}$ [11]. It is a hybrid chicken obtained from the cross of Suranaree University of Technology (SUT) as a dam line and the Thai native chickens (Leung Hang Khao, LHK) as a sire line. KRC is recognized for its meat quality and holds promise of being an efficient occupation for Thai smallholder farmers as well as smallholder farmers across Southeast Asia in the near future. However, it has not gained the expected levels of scientific interventions. Furthermore, though Southeast Asia is one of the largest chicken-producing regions, the efficiency of OR farming in Southeast Asia has not been explored fully. Therefore, to unveil the efficiency of OR for tropical areas, particularly Southeast Asia, it is essential to investigate the effects of OR on the growth performance and meat quality of slow-growing chickens compared to the conventional raising system.

Several studies have investigated the effect of OR on the growth performance and meat quality [12-15] of chickens; however, they have reported inconsistent results attributable to the differences in the breed, feed, and experimental sites used by them. Moreover, fatty acids (FA), particularly n-3 PUFA such as docosahexaenoic acid (DHA) and eicosapentaenoic acid (EPA), are expected to be higher in the meat of chickens that were raised in OR, because organic chickens can get $\alpha$-linolenic acid (ALA) from pasture, which is the precursor of n-3 PUFA [14]. Nevertheless, some studies have reported contradictory results for the effects of OR on the fatty acid profiles of meat [16].

The raising system affected lipid oxidation [17], resulting in a change in secondary protein structure (such as $\alpha$-helix and $\beta$-sheet) [18], and may alter the biochemical compositions in meat, or the contents of glycogen, which have been shown to play major roles in determining meat quality [19-21]. Therefore, it is expected that monitoring the changes in the biochemical composition of meat with high sensitivity could help understand and explain the effect of the raising system on meat quality. Fourier transform infrared microscopy is a powerful technique used for biological analysis and monitoring the changes in biochemical compositions at the molecular level [22]. However, the global light source used for this technique does not have enough power to penetrate the cell and a lower ability to detect changes compared with light sources from synchrotrons radiation [23].

Synchrotron Radiation-Fourier Transform Infrared (SR-FTIR) spectroscopy is a highly sensitive and powerful technique because it is extremely intense (hundreds of thousands of times more intense than that from conventional X-ray tubes) and highly collimated [24]. In addition, this technique is fast, inexpensive, and non-destructive compared to conventional methods. It can provide unique information and a high performance to detect biochemical compounds at the molecular level, such as proteins, lipids, and glycogen [25]. Moreover, the efficiency of FTIR spectroscopy to investigate the change in biochemical composition 
in KRC meat is evident from previous studies. For instance, Poompramun et al. [26] successfully evaluated the differences in the biochemical composition of KRC thigh meat from the high and low feed conversion ratio (FCR) groups. We hypothesized that SR-FTIR could help monitor the quality traits in meat obtained from different raising systems.

The present study investigates the effects of OR on the growth performance, physicochemical properties, and biochemical composition of meat using SR-FTIR in KRC. Furthermore, in this study, KRC was used-mainly to identify its potential as one of the representatives of slow-growing chickens in OR and represent itself.

\section{Materials and Methods}

\subsection{Ethics Statement}

In the present study, all procedures were approved by the Ethics Committee on Animal Use of SUT, Nakhon Ratchasima, Thailand (user application ID: U1-02633-2559).

\subsection{Birds, Experimental Design, and Diets}

This study was conducted from January to April 2018. The experimental site was located at the coordinates latitude $14^{\circ} 53^{\prime} 13^{\prime \prime} \mathrm{N}$ and longitude $101^{\circ} 59^{\prime} 42^{\prime \prime} \mathrm{E}$. The temperatures varied from $20.0-35.5^{\circ} \mathrm{C}$ with an average relative humidity of $76 \%$ (Nakhon Ratchasima Meteorological Department, Nakhon Ratchasima, Thailand). Before this study, heavy metal levels in water and soil were assessed, and the experimental area was not treated with pesticides or herbicides. All animals were raised according to the National Bureau of Agricultural Commodity and Food Standards [27].

Three hundred and sixty (1-day-old) mixed-sex Thai native crossbred chicks, KRC, were produced at the Poultry Research Unit of the University Farm. The chicks were vaccinated against Marek's disease on d 1, Newcastle disease and infectious bronchitis on $\mathrm{d} 7$ and 21, and Gumboro disease on d 14. After hatching, the chicks were randomly allocated to two different raising systems (considered treatment groups) using a completely randomized design-each treatment group comprised 6 pens and 30 chickens per pen. In the $\mathrm{CO}$ (control group), chickens were housed in an indoor pen (5 birds $/ \mathrm{m}^{2}$ ), fed with mixed feed derived from commercial feedstuffs, while the chickens in the OR group were fed with mixed feed derived from certificated organic feedstuffs in an indoor pen ( 5 birds $/ \mathrm{m}^{2}$ ) with free access to an outdoor Ruzi pasture $\left(4 \mathrm{~m}^{2} /\right.$ bird) from $\mathrm{d} 21$ of age to slaughter age (d 84). Ruzi pasture, planted from seed and grown by irrigation, is very palatable and tolerates moderately heavy grazing, and the chickens were allowed to eat this grass daily. The organic feed content in the starter, grower, and finisher diets fed to OR chickens were $96.20 \%, 96.65 \%$, and $96.85 \%$, respectively. The experimental diets used in both raising systems are shown in Table 1-the energy and protein levels of the diets were adjusted to the same level. The chickens had ad libitum access to feed and water throughout the experimental period.

Table 1. Compositions and calculated nutrient contents of starter, grower, and finisher diets $(\mathrm{g} / 100 \mathrm{~g}$ diet, as-fed basis).

\begin{tabular}{cccc}
\hline Item & $\begin{array}{c}\text { Starter } \\
(\mathbf{d} \text { 1 to d 21) }\end{array}$ & $\begin{array}{c}\text { Grower } \\
(\mathbf{d} \text { 22 to d 42) }\end{array}$ & $\begin{array}{c}\text { Finisher } \\
(\mathbf{d} \text { 43 to d 84) }\end{array}$ \\
\hline Full fat soybean meal $(37 \% \mathrm{CP})$ & 47.70 & 41.00 & 34.50 \\
Broken rice & 48.50 & 55.65 & 62.35 \\
DL-methionine $^{\text {Salt }}$ & 0.25 & 0.10 & 0.10 \\
CaCO $_{3}$ & 0.35 & 0.35 & 0.35 \\
Monocalcium phosphate (21\% P) & 1.40 & 1.30 & 1.20 \\
Premix $^{1}$ & 1.30 & 1.10 & 1.00 \\
& 0.50 & 0.50 & 0.50 \\
\hline
\end{tabular}


Table 1. Cont.

\begin{tabular}{cccc}
\hline Item & $\begin{array}{c}\text { Starter } \\
(\mathbf{d} \text { 1 to d 21) }\end{array}$ & $\begin{array}{c}\text { Grower } \\
(\mathbf{d} \text { 22 to d 42) }\end{array}$ & $\begin{array}{c}\text { Finisher } \\
\text { (d 43 to d 84) }\end{array}$ \\
\hline Calculated nutrients (\% unless stated otherwise) & & \\
ME (kcal/kg) & 3175 & 3190 & 3195 \\
Crude protein & 21.00 & 19.00 & 17.00 \\
Crude fat & 8.33 & 7.00 & 7.18 \\
Crude fiber & 2.73 & 2.37 & 2.05 \\
Digestible lysine & 1.21 & 1.08 & 0.95 \\
Digestible methionine & 0.59 & 0.43 & 0.41 \\
Digestible met + cys & 0.93 & 0.73 & 0.69 \\
Digestible threonine & 0.79 & 0.72 & 0.64 \\
Calcium & 1.01 & 0.91 & 0.84 \\
Available phosphorus & 0.45 & 0.38 & 0.35 \\
\hline
\end{tabular}

${ }^{1}$ Premix (0.5\%) provided the following per kilogram of diet: 15,000 IU of vitamin A; 3000 IU of vitamin D3; 25 IU of vitamin E; $5 \mathrm{mg}$ of vitamin K3; $2 \mathrm{mg}$ of thiamine; $7 \mathrm{mg}$ of riboflavin; $4 \mathrm{mg}$ of pyridoxine; $25 \mu \mathrm{g}$ of cobalamin; $11.04 \mathrm{mg}$ of pantothenic acid; $35 \mathrm{mg}$ of nicotinic acid; $1 \mathrm{mg}$ of folic acid; $15 \mu \mathrm{g}$ of biotin; $250 \mathrm{mg}$ of choline chloride; $1.6 \mathrm{mg}$ of copper; $60 \mathrm{mg}$ of manganese; $45 \mathrm{mg}$ of zinc; $80 \mathrm{mg}$ of iron; $0.4 \mathrm{mg}$ of iodine; $0.15 \mathrm{mg}$ of selenium.

\subsection{Measurements and Chemical Analyses}

\subsubsection{Growth Performance and Carcass Composition}

Growth performance was estimated by assessing the BW and feed intake (FI) every week, and subsequently, BW gain (BWG) and FCR were calculated. The percentages of eviscerated carcasses and abdominal fat were measured as a ratio of the live chicken's BW after feed withdrawal. The percentages of the breast, thigh, and drumstick were estimated as the percentages of the chilled carcass weight.

\subsubsection{Sample Collection}

At slaughter age (d 84), 24 chickens from each group were randomly selected and electrically stunned, and their feathers were removed with a machine. Then, they were scalded and eviscerated manually. The carcass composition and meat quality were measured in 12 chickens per treatment ( 6 males and 6 females). The proximate composition, FA profile, cholesterol content, and nucleotide content were estimated from the breast and thigh meat samples obtained from the remaining 12 chickens (6 males and 6 females). The samples were stored at $-20{ }^{\circ} \mathrm{C}$ till analyses.

\subsubsection{Drip Loss Measurement}

The breast and thigh meat samples were cut into $1.5 \mathrm{~cm}$ (width) $\times 3.0 \mathrm{~cm}$ (length) $\times 0.5 \mathrm{~cm}$ (thickness) pieces from the same position after chilling for $24 \mathrm{~h}$. Then, the cut meat samples were hung inside a chilled storage room at $4{ }^{\circ} \mathrm{C}$ for $24 \mathrm{~h}$. The drip loss was estimated by using the following formula:

$$
\operatorname{Drip} \operatorname{Loss}(\%)=\frac{\left(\text { Weight }_{\text {before storage }}-\text { Weight }_{\text {after storage }}\right)}{\text { Weight }_{\text {before storage }}} \times 100
$$

\subsubsection{Cooking Loss Measurement}

After thawing the breast and thigh samples overnight, they were weighed and boiled in a water bath in open plastic bags until an internal temperature of $80^{\circ} \mathrm{C}$ was reached. Cooking loss was calculated as follows:

$$
\text { Cooking Loss }(\%)=\frac{\left(\text { Weight }_{\text {before boiling }}-\text { Weight }_{\text {after boiling }}\right)}{\text { Weight }_{\text {before boiling }}} \times 100
$$




\subsubsection{Warner-Bratzler Shear Force Measurement}

A texture analyzer (TA-XT2, Texture Technologies Corp., Scarsdale, NY, USA) was used to determine the shear force of the cooked breast and thigh samples. At least two subsamples of $2.0 \mathrm{~cm}$ (width) $\times 3.0 \mathrm{~cm}$ (thickness) $\times 0.5 \mathrm{~cm}$ (length) were cut parallel to the muscle fibers. The crosshead speed was set at $20 \mathrm{~cm} / \mathrm{min}$, and the shear force was calculated following the method described by Wattanachant et al. [28].

\subsubsection{Morphological Analysis}

Tissue samples were fixed in $10 \%$ formalin solution for $24 \mathrm{~h}$ at room temperature, dehydrated, and embedded in paraffin wax. Tissue sections $(3 \mu \mathrm{m})$ were stained with hematoxylin and eosin ( $\mathrm{H} \& \mathrm{E})$. The changes in muscle morphology were visualized using a light microscope (Olympus CX21, Hicksville, NY, USA) and the ZEN software (Axis Cam ERc5s-Zen lite, 2012). The ImageJ program was used for muscle fiber diameter analysis modifying the procedure described in a previous study [29].

\subsubsection{Proximate Analysis}

Proximate analysis of meat was performed following the standardized method of the Association of Official Analytical Chemists [30]. Briefly, $2 \mathrm{~g}$ breast and thigh meat samples were both dried at $102{ }^{\circ} \mathrm{C}$ for $15 \mathrm{~h}$ to estimate the moisture content. The crude protein (CP) percentage was determined using the Kjeldahl method (VAPO45, Gerhardt Ltd., Idar-Oberstein, Germany), and the total crude fat content was determined following the protocol of Jeon et al. [31].

\subsubsection{Fatty Acid Profile Measurement}

Total lipids were extracted from breast and thigh samples. Briefly, $5 \mathrm{~g}$ breast and thigh meat samples were both dissolved in $90 \mathrm{~mL}$ chloroform-methanol (2:1, v/v), and total lipid was extracted following the method described in a previous study [32]. Subsequently, fatty acid methyl esters (FAMEs) were prepared by methylation following the procedure reported by Metcalfe et al. [33]. The FAMEs were analyzed using gas chromatography (Hewlett-Packard 7890A; Agilent Technologies, Santa Clara, CA, USA) fitted with a capillary column (SP 2560, Supelco Inc., Bellefonte, PA, USA, $100 \mathrm{~m} \times 0.25 \mathrm{~mm}$ i.d., $0.20-\mu \mathrm{m}$ film thickness) and a flame ionization detector. Helium was used as the carrier gas at a flow rate of $0.95 \mathrm{~mL} / \mathrm{min}$. The temperatures of the injector and detector were set at $260{ }^{\circ} \mathrm{C}$. The injector and detector temperatures were set to $260{ }^{\circ} \mathrm{C}$. The oven temperature was programmed to increase from $70^{\circ} \mathrm{C}$ to $175^{\circ} \mathrm{C}$ at a rate of $13^{\circ} \mathrm{C} / \mathrm{min}$, and then rise to $240^{\circ} \mathrm{C}$ at a rate of $4{ }^{\circ} \mathrm{C} / \mathrm{min}$.

\subsubsection{Total Collagen Content Measurement}

Total collagen content was estimated following the method described by da Silva et al. [34] with some modifications. Briefly, $50 \mathrm{mg}$ breast and thigh meat samples were both hydrolyzed in $1 \mathrm{~mL} 7 \mathrm{M} \mathrm{NaOH}$ in an autoclave at $121^{\circ} \mathrm{C}$ for $40 \mathrm{~min}$. Sulfuric acid (3.5 M) was used to neutralize the hydrolyzed samples to a $\mathrm{pH}$ of 7 . Then, the neutralized samples were filtered and mixed with chloramine T solution and Ehrlich's reagent. Afterward, the absorbance at $550 \mathrm{~nm}$ (Genesys 10S UV-VIS, Thermo Fisher Scientific, Madison, WI, USA) was measured using hydroxyproline (Sigma-Aldrich Co., St. Louis, MO, USA) as a standard. A coefficient of 7.25 was used to calculate the total collagen content [35]. The collagen content was expressed in $\mathrm{mg}$ of collagen per $\mathrm{g}$ of meat.

\subsubsection{Nucleotide Content Measurement}

To extract the nucleic acids, $5 \mathrm{~g}$ breast and thigh meat samples were both mixed with $30 \mathrm{~mL}$ ice-cold $7.5 \%$ perchloric acid and homogenized for $30 \mathrm{~s}$. Next, $10 \mathrm{~mL}$ ice-cold 7.5\% perchloric acid was added and centrifuged at $2000 \times g$ at $4{ }^{\circ} \mathrm{C}$ for $5 \mathrm{~min}$. The solution was then filtered through a filter paper (No.1, Whatman International Ltd., Maidstone, UK). The filtrate $(1 \mathrm{~mL})$ was analyzed using high-performance liquid chromatography (HPLC) 
(HP 1260, Agilent Technologies, Inc., Santa Clara, CA) fitted with a Hypersil ODS C18 column $(3 \mu \mathrm{m}, 150 \mathrm{~mm} \times 4.6 \mathrm{~mm})$ (Thermo Scientific, Waltham, MA, USA). The analytical conditions for HPLC were set following Kim et al. [36] with some modifications. The peaks of the individual nucleotides were identified using the retention times estimated for the standards: inosine-5'-monophosphate (IMP) and guanosine-5'-monophosphate (GMP) (both obtained from Sigma, St. Louis, MO, USA), and the concentration of each nucleotide was estimated from the peak area of the individual nucleotides.

\subsubsection{Cholesterol Measurement}

The cholesterol content in the meat samples was estimated by gas chromatography following the method described by Rowea et al. [37] with some modifications. The $\alpha$-cholesterol was used as the internal standard. The gas chromatograph fitted with a flame ionization detector equipped with an HP-5 column $(30 \mathrm{~m} \times 0.32 \mathrm{~mm}$; film thickness, $0.22 \mu \mathrm{m}$; Agilent Technologies, Palo Alto, CA, USA) was used for the analysis. The injection port and detector temperature were set at $260{ }^{\circ} \mathrm{C}$ and $255^{\circ} \mathrm{C}$, respectively. Cholesterol was identified by comparing the relative retention time of the sample with that of the standard (Cargo Erba Reagents, Milan, Italy).

\subsection{Synchrotron Radiation-Based Fourier Transform Infrared (SR-FTIR) Spectroscopy \\ 2.4.1. Sample Preparation}

Breast samples were cut into $1 \mathrm{~cm} \times 1 \mathrm{~cm}$ pieces and placed in an aluminum foil block filled with optimal cutting temperature (OCT). Subsequently, the cut samples were completely embedded in OCT and immediately fixed in liquid nitrogen. The breast samples were then cut into sections using a cryostat (micron/HM 525) until the region of interest was reached. The optimized thicknesses of the tissue sections were $6 \mu \mathrm{m}$ for infrared measurement. The breast sample sections were then kept in a desiccator with a vacuum pump for $30 \mathrm{~min}$.

\subsubsection{SR-FTIR Spectra Measurement}

The biochemical composition of the samples was analyzed using SR-FTIR spectroscopy [38]. Spectral data were collected using the infrared microspectroscopy beamline BL4.1 IR Spectroscopy and Imaging at the Synchrotron Light Research Institute (SLRI, Nakhon Ratchasima, Thailand). Spectra were obtained using a Vertex 70 FTIR spectrometer (Bruker Optics, Ettlingen, Germany) coupled to an IR microscope (Hypersion 2000, Bruker), equipped with a liquid nitrogen cooled MCT detector. The data were collected over the 4000 to $800 \mathrm{~cm}^{-1}$ measurement range. The measurement was performed in mapping mode with an aperture size of $10 \mu \mathrm{m} \times 10 \mu \mathrm{m}$ and acquisition of 64 scans with a spectral resolution of $4 \mathrm{~cm}^{-1}$. The software OPUS 7.2 (Bruker Optics Ltd, Ettilngen, Germany) was used for the derivation of the spectra and instrument control, and the results were analyzed with the CytoSpec software.

Samples from CO and OR (12 samples per group) were used to investigate the changes in the biochemical composition of meat. First, the original spectra were averaged to obtain a total of five spectra, followed by the second derivation at 13 smoothing points, and the vector was normalized using the Savitzky-Golay method in Unscrambler X software (version 10.1, Camo Analytics, Oslo, Norway) to account for the effects of varying sample thickness.

\subsubsection{Relative Integral Area for Each Functional Group}

The relative integral areas were calculated from the second derivative spectra in the spectral region from 3000 to $900 \mathrm{~cm}^{-1}$ as follows: 3000 to $2800 \mathrm{~cm}^{-1}$ (CH stretching of lipid), $1740 \mathrm{~cm}^{-1}$ (C=O ester of lipid), 1700 to $1600 \mathrm{~cm}^{-1}$ (amide I), 1600 to $1500 \mathrm{~cm}^{-1}$ (amide II), $1338 \mathrm{~cm}^{-1}$ (amide III), and 1250 to $900 \mathrm{~cm}^{-1}$ (carbohydrate and glycogen) using OPUS software (version 7.2, Bruker Optics Ltd.), as shown in Table 2. 
Table 2. Relationship between molecular functional group and biomolecules.

\begin{tabular}{|c|c|c|c|}
\hline Wavenumber $\left(\mathrm{cm}^{-1}\right)$ & Chemical Function & Assignment & References \\
\hline 2930 to 2910 & $\mathrm{CH}_{2}$ asymmetric stretch & Mainly saturated lipids, proteins & [39] \\
\hline $\begin{array}{l}2970,2957 \text { to } 2953 \\
2875 \text { to } 2870\end{array}$ & $\begin{array}{l}\mathrm{CH}_{3} \text { asymmetric stretching } \\
\mathrm{CH}_{3} \text { symmetric stretching }\end{array}$ & $\begin{array}{l}\text { Lipids (mainly), proteins } \\
\text { Lipids, proteins }\end{array}$ & {$[40]$} \\
\hline 1700 to 1600 & $\mathrm{C}=\mathrm{O}$ stretching & Amide I band of proteins & [41] \\
\hline 1655,1650 to 1640 & $\mathrm{C}=\mathrm{O}$ stretching & Amide I of $\alpha$-helical structures of proteins & {$[42,43]$} \\
\hline 1695 to 1685 & $\mathrm{C}=\mathrm{O}$ stretching & Antiparallel $\beta$-sheet & [41] \\
\hline 1550 to 1520 & $\begin{array}{l}\mathrm{C}-\mathrm{N} \text { stretching }+\mathrm{N}-\mathrm{H} \text { bending } \\
\text { coupled in of face }\end{array}$ & Amide II band of proteins & [43] \\
\hline 1310 to 1240 & $\begin{array}{l}\mathrm{C}-\mathrm{N} \text { stretching }+\mathrm{N}-\mathrm{H} \text { bending } \\
\text { coupled in of face }\end{array}$ & Amide III of proteins & {$[40,43]$} \\
\hline 1637 to 1615 & $\mathrm{C}=\mathrm{O}$ stretching & $\beta$-sheet & {$[40,43,44]$} \\
\hline $\begin{array}{l}1681 \text { to } 1664 \\
1685 \text { to } 1675\end{array}$ & $\mathrm{C}=\mathrm{O}$ stretching & $\beta$-turn & {$[44,45]$} \\
\hline 1200 to 900 & $\begin{array}{l}\text { C-O-C, C-O dominated } \\
\text { by ring vibrations of } \\
\text { carbohydrates C-O-P, P-O-P }\end{array}$ & $\begin{array}{l}\text { Carbohydrate and } \\
\text { Glycogen }\end{array}$ & [40] \\
\hline
\end{tabular}

\subsubsection{Curve Fitting for the Amide I Band}

The peak positions and band shapes were selected for curve fitting, which examines the area of overlapping peaks of the amide I band $\left(1700\right.$ to $\left.1600 \mathrm{~cm}^{-1}\right)$ in the FTIR spectra using a nonlinear least square approach based on Gaussian and Lorentzian functions. The fitting parameters, such as beta-sheet (1645 to $\left.1620 \mathrm{~cm}^{-1}\right)$, alpha-helix $\left(1640\right.$ to $1650 \mathrm{~cm}^{-1}$ ), beta-turn (1685 to $1675 \mathrm{~cm}^{-1}$ ), and anti-parallel (1695 to $1685 \mathrm{~cm}^{-1}$ ) were measured.

\subsection{Statistical Analyses}

The significant differences of the mean values of growth performance traits, carcass composition, breast meat quality, biochemical compositions, and FA content of KRC meat between CO and OR were analyzed by t-test using SPSS software (version 16.0; SPSS Inc., Chicago, IL, USA). All data are expressed as mean $\pm \mathrm{SD}$, and a $p$-value of $<0.05$ was considered significant.

The interaction of the spectral data matrix between $\mathrm{CO}$ and OR chicken samples, meat quality, n-3 PUFA content, secondary protein structures, and biochemical compounds (spectra intensity from 3000 to $1000 \mathrm{~cm}^{-1}$ ) from FTIR was generated. The clustering of the variables was analyzed using principal component analysis (PCA). The relationships between variables and sample properties were identified using biplot obtained by the calculations from a two-dimensional scatter plot of PCA with the dominant spectral band of the different variables.

The correlation between meat quality, n-3 PUFA content, secondary protein structures, and biochemical compounds for each cluster of the control and organic chicken samples in the data matrix were weighted using an SD weighting process and calculated using PCA, after which a biplot correlation between variables was created using multivariate analysis.

\section{Results and Discussion}

\subsection{Growth Performance and Carcass Yield}

The growth performance and carcass yield of chickens are shown in Tables 3 and 4, respectively. It was observed that the final $\mathrm{BW}$ of the $\mathrm{OR}$ and $\mathrm{CO}$ chickens did not differ $(p>0.05)$, whereas the FI and FCR of the OR chickens were lower than those of CO $(p<0.001)$. The results were inconsistent with our hypothesis that chickens reared in OR would be exposed to fluctuating temperature and increased activity in the yard requiring 
higher energy, consequently leading to decreased BW and increased FCR. Our hypothesis aligns with the findings of Mattioli et al. [46], who reported that exercise behavior is negatively correlated with the performance of chickens, as high movement can increase energy metabolism and decrease their growth performance. Although several studies related to the effect of OR on growth performance have been reported [12,47,48], the results of these studies, including those of the present study, show inconsistency, which could be attributed to the differences in the rearing environmental factors, including light intensity, photoperiod, temperature, breed of chicken, diet, forages, insects, and worms found in pasture [20]. Likewise, several studies have shown that the raising environment affects the quality of grass [49], natural diet [50,51], and diversity of microorganisms in a specific area [52]. Furthermore, in concordance with the results of previous studies, the reduced FI of OR chickens could also be attributed to their free access to natural diets from the rearing environment $[10,53]$. The lower FCR in OR chickens than in CO chickens with no significant differences in their BW could be due to the enrichment of the digestive tract of OR chicken with some beneficial microorganisms, which might have contributed to the activation of the beneficial enzymes, consequently leading to increased utilization of protein or carbohydrate from grass [54]. However, as the present study was aimed to identify the effects of raising systems on growth performance, we did not explore the precise role of different feed sources such as natural or commercial diets on gut microbiota composition. Therefore, further in-depth studies are needed to understand the effect of OR on the gut microbiota of chicken.

Table 3. Effects of organic raising system on growth performance of Korat chicken at $84 \mathrm{~d}$ of age (mean $\pm \mathrm{SD})$.

\begin{tabular}{cccc}
\hline Item & CO & OR & $p$-Value \\
\hline Final BW $(\mathrm{g})$ & $1480.31 \pm 37.94$ & $1445.56 \pm 42.90$ & 0.558 \\
FI (g) & $3634.74 \pm 32.22^{\mathrm{a}}$ & $3074.69 \pm 21.37^{\mathrm{b}}$ & $<0.0001$ \\
BWG $(\mathrm{g})$ & $1434.60 \pm 37.74$ & $1399.68 \pm 42.80$ & 0.554 \\
FCR & $2.54 \pm 0.06^{\mathrm{a}}$ & $2.20 \pm 0.07^{\mathrm{b}}$ & 0.004 \\
\hline
\end{tabular}

$\mathrm{a}, \mathrm{b}$ Means within a row with different superscript letters differ significantly at $p<0.05 . \mathrm{CO}=$ control, $\mathrm{OR}=$ organic raising system.

Table 4. Effects of organic raising system on carcass composition of Korat chicken at $84 \mathrm{~d}$ of age (mean $\pm \mathrm{SD})$.

\begin{tabular}{cccc}
\hline Yield (\%) & CO & OR & $p$-Value \\
\hline Eviscerated carcass & $63.90 \pm 0.94$ & $63.67 \pm 0.84$ & 0.941 \\
Pectoralis minor & $3.27 \pm 0.12$ & $3.05 \pm 0.13$ & 0.247 \\
Pectoralis major & $8.64 \pm 0.20$ & $8.49 \pm 0.30$ & 0.680 \\
Thigh meat & $10.06 \pm 0.26$ & $10.38 \pm 0.35$ & 0.464 \\
Drumstick meat & $10.02 \pm 0.37$ & $9.68 \pm 0.30$ & 0.477 \\
Abdominal fat & $1.47 \pm 0.15^{\mathrm{a}}$ & $1.05 \pm 0.11^{\mathrm{b}}$ & 0.029 \\
\hline
\end{tabular}

$\overline{\mathrm{a}, \mathrm{b}}$ Means within a row with different superscript letters differ significantly at $p<0.05 .{ }^{1}$ Carcass weights without viscera, head, neck, feet, and shank. $\mathrm{CO}=$ control, $\mathrm{OR}=$ organic raising system.

Furthermore, the findings demonstrated no differences $(p>0.05)$ in carcass yields of the OR and CO chickens, whereas the yield of abdominal fat in chickens from OR was lower $(p=0.029)$ than that of the chickens from $\mathrm{CO}$, as reported in previous studies $[12,55]$. Though it was expected that the carcass yield of chickens in OR would be higher than that of chickens in $\mathrm{CO}$ because the formers have more activity during the day, resulting in the process of muscle repair and increased muscle fiber size (hypertrophy), our study, like the study of Castellini et al. [12], did not adhere to the above expectations. This could be due to the high temperature $\left(20.0-35.5^{\circ} \mathrm{C}\right)$ during the experimental period (summer) of this study that might have restricted the chickens to stay close to their house, leading to reduced exercise and motor activities; hence, no gain in muscle mass. In contrast, Comert et al. [9] 
have demonstrated a higher amount of abdominal fat in chicken grown in the OR system than those grown in the CO system. This difference could be attributed to the different genotypes and the sex of birds used in the two studies. Taken together, we inferred that the OR chickens are exposed to increased physical activity than the CO chickens, which, though increases the energy metabolism rate and reduces the abdominal fat accumulation, is not sufficient enough to increase the carcass yield. Furthermore, sex and genotype are the other important factors affecting the carcass characteristics and, therefore, should be carefully considered $[9,56]$.

\subsection{Physicochemical Properties of Chicken Meat}

The effects of the raising system on the biochemical composition of OR chicken meat are presented in Table 5. The results demonstrated that except for protein and total collagen content, the raising system had no effects $(p>0.05)$ on moisture, cholesterol, fat, IMP, and GMP contents in breast and thigh meat. However, the protein and total collagen contents were higher $(p<0.05)$ in OR meat than in $\mathrm{CO}$ meat.

Table 5. Effects of organic raising system on biochemical composition of Korat chicken at $84 \mathrm{~d}$ of age (mean $\pm \mathrm{SD}$ ).

\begin{tabular}{|c|c|c|c|}
\hline \multirow{2}{*}{ Item } & \multicolumn{2}{|c|}{ Treatment } & \multirow{2}{*}{$p$-Value } \\
\hline & $\mathrm{CO}$ & OR & \\
\hline \multicolumn{4}{|l|}{ Breast meat } \\
\hline Moisture (\%) & $73.74 \pm 1.20$ & $72.89 \pm 0.92$ & 0.580 \\
\hline Crude Protein (\%) & $23.58 \pm 0.12^{b}$ & $24.54 \pm 0.07^{\mathrm{a}}$ & $<0.0001$ \\
\hline Crude fat $(\%)$ & $1.99 \pm 0.10$ & $1.93 \pm 0.15$ & 0.430 \\
\hline Cholesterol (mg/100 g meat) & $59.04 \pm 6.91$ & $52.68 \pm 4.78$ & 0.450 \\
\hline Total collagen (mg/g meat) & $0.85 \pm 0.05^{b}$ & $1.02 \pm 0.05^{\mathrm{a}}$ & 0.030 \\
\hline IMP (mg/g meat) & $0.14 \pm 0.00$ & $0.13 \pm 0.00$ & 0.150 \\
\hline GMP (mg/g meat) & $4.93 \pm 0.12$ & $5.09 \pm 0.09$ & 0.150 \\
\hline \multicolumn{4}{|l|}{ Thigh meat } \\
\hline Moisture (\%) & $74.04 \pm 0.30$ & $73.03 \pm 0.14$ & 0.060 \\
\hline Crude Protein (\%) & $13.74 \pm 0.04^{\mathrm{b}}$ & $14.44 \pm 0.04^{\mathrm{a}}$ & $<0.0001$ \\
\hline Crude fat $(\%)$ & $5.64 \pm 0.35$ & $5.43 \pm 0.35$ & 0.508 \\
\hline Cholesterol (mg/100 g meat) & $79.89 \pm 9.01$ & $76.37 \pm 5.74$ & 0.720 \\
\hline Total collagen (mg/g meat) & $0.73 \pm 0.03^{b}$ & $1.08 \pm 0.06^{\mathrm{a}}$ & $<0.0001$ \\
\hline IMP (mg/g meat) & $0.15 \pm 0.00$ & $0.16 \pm 0.00$ & 0.220 \\
\hline GMP (mg/g meat) & $3.73 \pm 0.22$ & $4.18 \pm 0.28$ & 0.100 \\
\hline
\end{tabular}

$\overline{\mathrm{a}, \mathrm{b}}$ Means within a row with different superscript letters differ significantly at $p<0.05 . \mathrm{CO}=$ control, $\mathrm{OR}=$ organic raising system.

IMP and GMP are key compounds contributing to flavor [57]; in addition, they participate in energy metabolism and ensure energy supply to cells. IMP is generated from the process of adenosine triphosphate (ATP) consumption [58], and ATP is produced when an animal has any activity [58,59]. Moreover, IMP can be converted to GMP [60]. Considering these, it can be inferred that the physical activities might not be sufficiently different in OR chicken than the $\mathrm{CO}$ chicken; therefore, no significant differences were observed for IMP, GMP, cholesterol, and crude fat between OR and CO chicken meat samples.

On the contrary, the increased protein and collagen contents suggested that the access to the outdoors increased the physical activity in OR chickens, which was sufficient to alter these components, and indicated that these two traits could be highly sensitive to physical activities. In concordance with the above speculation, Miller et al. [61] have reported that the rate of skeletal muscle collagen and sarcoplasmic protein synthesis increased markedly and rapidly after exercise. Moreover, the results of the present study are congruent with those of the previous studies [5,6,62]. Mikulski et al. [62] reported that the highest protein content was detected in the meat of chicken raised in outdoor access, about $12 \mathrm{~h}$ a day, from $\mathrm{d} 21$ to $\mathrm{d} 64$. It has been shown that organic chickens which forage on pasture $12 \mathrm{~h}$ 
daily, (depending on the condition each day) exhibited greater activity from d 21 to $\mathrm{d} 84$, resulting in more type IIA muscle fibers, and were able to synthesize more protein [63]. Collectively, the findings of the present study and those of the previous studies suggest that rearing chickens with outdoor access could increase $\mathrm{CP}$ and total collagen content in meat.

The results for the physicochemical properties of meat shown in Table 6 indicate that raising systems had no significant effect on most traits, except for shear force and color, whose values were higher $(p<0.001)$ in OR chicken than in CO chicken.

Table 6. Effects of organic raising system on breast meat quality of Korat chicken at $84 \mathrm{~d}$ of age (mean \pm SD).

\begin{tabular}{cccc}
\hline Item & CO & OR & $p$-Value \\
\hline Ultimate $\mathrm{pH}$ & $5.40 \pm 0.02$ & $5.35 \pm 0.02$ & 0.079 \\
Drip loss (\%) & $11.93 \pm 0.66$ & $12.27 \pm 0.62$ & 0.874 \\
Cooking loss (\%) & $22.84 \pm 0.95$ & $23.09 \pm 0.55$ & 0.570 \\
Shear force (WBS) & $2.17 \pm 0.04^{\mathrm{b}}$ & $2.63 \pm 0.10^{\mathrm{a}}$ & $<0.0001$ \\
\hline Skin color & & & 0.057 \\
\hline Lightness & $66.96 \pm 0.59$ & $65.34 \pm 2.47$ & 0.004 \\
Redness & $-0.47 \pm 0.19^{\mathrm{b}}$ & $0.30 \pm 0.15^{\mathrm{a}}$ & $<0.0001$ \\
Yellowness & $7.02 \pm 0.37^{\mathrm{b}}$ & $15.50 \pm 0.66^{\mathrm{a}}$ & \\
\hline Meat color & & & 0.591 \\
\hline Lightness & $52.21 \pm 0.65$ & $51.37 \pm 0.55$ & 0.031 \\
Redness & $-0.29 \pm 0.18^{\mathrm{b}}$ & $0.35 \pm 0.13^{\mathrm{a}}$ & $<0.0001$ \\
Yellowness & $3.49 \pm 0.28^{\mathrm{b}}$ & $7.27 \pm 0.44^{\mathrm{a}}$ & 0.056 \\
\hline Muscle diameter $(\mu \mathrm{m})$ & $22.34 \pm 0.51$ & $23.88 \pm 0.56$ & \\
\hline
\end{tabular}

$\mathrm{a}, \mathrm{b}$ Means within a row with different superscript letters differ significantly at $p<0.05$. $\mathrm{CO}=$ control, $\mathrm{OR}=$ organic raising system. WBS $=$ Warner-Bratzler shear force $\left(\mathrm{kgf} / 0.5 \mathrm{~cm}^{2}\right)$.

Generally, the ultimate $\mathrm{pH}$ is largely determined by the initial glycogen storage in the muscle, and the decline in muscle $\mathrm{pH}$ is related to glycolysis activity under anaerobic conditions [64], wherein lower $\mathrm{pH}$ is related to higher drip loss and cooking loss [65]. This could be because a decline in the muscle $\mathrm{pH}$ causes a reduction in the net charge of muscle protein and charged protein sites for binding of water molecules, resulting in greater water and nutrient losses [66]. However, in this study, the raising systems demonstrated no effect on $\mathrm{pH}$, drip loss, and cooking loss. These results suggested that the energy expenditure might not significantly affect the rate of glycolysis in the chickens from both raising systems.

Shear force and muscle diameter indicate tenderness [67]. Increased shear force is the consequence of higher protein and collagen levels in the meat sample. Furthermore, it is known that chicken breast meat is composed of type IIB muscle fibers [59], and prolonged exercise training can induce the transition of type IIB muscle fibers to type IIA muscle fibers. The latter fiber type has a high capacity to generate ATP by oxidative metabolic processes. Therefore, it requires more oxygen to maintain its activity and induce protein synthesis, leading to increased muscle diameter $[68,69]$. In this study, the muscle diameter of OR chicken meat was slightly larger $(p=0.056)$ than CO chicken, which indicated that the OR chickens have higher movement, though not significant, leading to adaptive changes in the skeletal muscle fiber.

The greater redness $(p=0.004)$ and yellowness $(p<0.0001)$ of OR meat and skin observed in this study agree with those reported in the study of Grashorn and Serini [5]. It could be attributed to the consumption of grasses, a major source of carotenoid pigments $[16,62,70]$, as the OR chickens had free access to the grass fields.

\subsection{Fatty Acid Profile of Chicken Meat}

The FA profiles in the breast and thigh meat of OR and $\mathrm{CO}$ chickens are shown in Table 7. No differences in saturated fatty acids (SFA), monounsaturated fatty acids (MUFA), and PUFA content of KRC meat were detected in the different raising systems $(p>0.05)$. In 
contrast, the proportion of total n-3 PUFA in breast and thigh meat of chickens raised under OR was higher $(p=0.01)$ than in those raised under CO. Moreover, the DHA (C22:6n-3) content was higher $(p=0.01)$ in breast meat. However, the ratio of $n-6$ to $n-3$ PUFA was lower in the breast $(p<0.001)$ and thigh $(p=0.02)$ of OR chickens. It has been shown that FA from the diet strongly influences the amount of FA in meat [71]. Similarly, grass intake has been shown to increase antioxidants content in plasma and consequently decrease FA oxidation [45]. In addition, fresh grass contains 50-75\% ALA [72], a precursor of long-chain n-3 PUFA. It can be converted to EPA (C20:5n-3), docosapentaenoic acid (DPA, C22:5n-3), and DHA (C22:6n-3) through the biochemical processes of elongation and desaturation [14]. Moreover, previous studies reported that slow-growing chickens have higher expression of FADS1 and FADS2 genes involved in n-3 PUFA and n-6 PUFA metabolism [73] and can maintain their oxidative stability during their activity than fast-growing chickens [46]. Considering these, the increased level of DHA in KRC breast meat could be attributed to the influence of the consumption of pastures by the OR chickens. At the same time, the non-increase in DHA content in the thigh meat could be explained by the different lipid compositions in breast and thigh meat. The DHA content is preferentially stored in the form of phospholipids than triglycerides. These results are consistent with Bou et al. [74], who reported that the ratio of phospholipids to triglycerides is higher in breast meat than in thigh meat.

Table 7. Major fatty acid profiles (g/100 g total FA) of skinless breast and thigh meat from organic chickens (mean $\pm \mathrm{SD}$ ).

\begin{tabular}{ccccccc}
\hline \multirow{2}{*}{ Fatty Acid } & \multicolumn{3}{c}{ Breast Meat } & & \multicolumn{3}{c}{ Thigh Meat } \\
\cline { 2 - 7 } & CO & OR & $p$-Value & CO & OR & $p$-Value \\
\hline C14:0 & $0.90 \pm 0.37$ & $0.96 \pm 0.48$ & 0.92 & $0.39 \pm 0.01$ & $0.38 \pm 0.02$ & 0.79 \\
C16:0 & $18.27 \pm 0.22$ & $17.54 \pm 0.30$ & 0.06 & $16.81 \pm 0.46$ & $16.99 \pm 0.48$ & 0.79 \\
C16:1 & $1.53 \pm 0.16$ & $1.16 \pm 0.25$ & 0.23 & $2.01 \pm 0.24$ & $2.09 \pm 0.25$ & 0.82 \\
C18:0 & $8.28 \pm 0.13$ & $8.63 \pm 0.26$ & 0.24 & $7.61 \pm 0.36$ & $7.42 \pm 0.21$ & 0.66 \\
C18:1n-9 & $24.56 \pm 0.89$ & $25.78 \pm 1.50$ & 0.65 & $26.66 \pm 0.75$ & $28.67 \pm 0.83$ & 0.07 \\
C18:2n-6 & $31.09 \pm 0.20$ & $28.91 \pm 0.11$ & 0.11 & $37.45 \pm 1.11$ & $34.90 \pm 0.99$ & 0.49 \\
C18:3n-6 & $0.13 \pm 0.08$ & $0.11 \pm 0.09$ & 0.87 & $0.26 \pm 0.01$ & $0.22 \pm 0.02$ & 0.30 \\
C18:3n-3 & $2.12 \pm 0.15$ & $2.25 \pm 0.21$ & 0.62 & $3.51 \pm 0.16$ & $3.77 \pm 0.14$ & 0.24 \\
C20:2n-6 & $0.30 \pm 0.03$ & $0.35 \pm 0.04$ & 0.30 & $0.28 \pm 0.02$ & $0.28 \pm 0.04$ & 0.90 \\
C20:3n-6 & $0.53 \pm 0.04$ & $0.63 \pm 0.05$ & 0.13 & $0.24 \pm 0.02$ & $0.27 \pm 0.01$ & 0.33 \\
C20:4n-6 & $9.58 \pm 0.86$ & $10.50 \pm 0.91$ & 0.21 & $3.98 \pm 0.44$ & $3.15 \pm 0.45$ & 0.20 \\
C20:5n-3 & $0.13 \pm 0.05$ & $0.16 \pm 0.09$ & 0.72 & $0.16 \pm 0.11$ & $0.03 \pm 0.02$ & 0.29 \\
C22:6n-3 & $1.11 \pm 0.07^{\mathrm{b}}$ & $1.75 \pm 0.19^{\mathrm{a}}$ & 0.01 & $0.41 \pm 0.05$ & $0.67 \pm 0.13$ & 0.09 \\
SFA & $27.73 \pm 0.50$ & $27.13 \pm 0.58$ & 0.32 & $24.80 \pm 0.59$ & $24.79 \pm 0.52$ & 0.40 \\
MUFA & $27.29 \pm 1.00$ & $28.82 \pm 1.62$ & 0.29 & $28.89 \pm 0.89$ & $31.08 \pm 0.96$ & 0.07 \\
PUFA & $44.98 \pm 0.83$ & $44.04 \pm 0.85$ & 0.31 & $46.31 \pm 1.14$ & $44.13 \pm 1.36$ & 0.27 \\
Total n-6 & $40.79 \pm 0.77$ & $39.87 \pm 0.83$ & 0.18 & $41.94 \pm 1.02$ & $38.59 \pm 0.94$ & 0.19 \\
Total n-3 & $3.36 \pm 0.14^{\mathrm{b}}$ & $4.17 \pm 0.18^{\mathrm{a}}$ & $<0.001$ & $4.09 \pm 0.15^{\mathrm{b}}$ & $5.27 \pm 0.18^{\mathrm{a}}$ & 0.01 \\
n-6/n-3 & $12.14 \pm 0.54^{\mathrm{a}}$ & $9.57 \pm 0.40^{\mathrm{b}}$ & $<0.001$ & $10.26 \pm 0.21{ }^{\mathrm{a}}$ & $7.33 \pm 0.63 \mathrm{~b}$ & 0.02 \\
\hline
\end{tabular}

a,b Means within a row with different superscript letters differ significantly at $p<0.05$. CO = control, $\mathrm{OR}=$ organic raising system, SFA = saturated fatty acids, MUFA = monounsaturated fatty acids, PUFA =polyunsaturated fatty acids.

Furthermore, a lower ratio of n-6 to n-3 PUFA in the meat of OR chickens owing to increased n-3 PUFA levels could also be due to the competition of FA for desaturase and elongase enzymes [75]. In concordance, Lopez-Ferrer et al. [76] have also reported that the high levels of n-3 PUFA intake may have reduced the desaturase and elongase enzymes of the precursors of n-6 PUFA, leading to low n-6 to n-3 PUFA in organic KRC meat. Interestingly, OR chicken showed a ratio of n-6 to n-3 lower than 10, which is beneficial for human health [77].

Dal Bosco et al. [10] reviewed several studies and reported an interaction between the genetic strain with movement, intake of antioxidants, the antioxidant capacity of the body, plasma, and fatty acid profile meat. The study demonstrated that selected strains, higher 
kinetic activity, and the less controlled environmental conditions exacerbate oxidative status and fatty acid profile of the meat. Therefore, this relationship must be analyzed in future studies. Measurement of enzyme activity and expression of genes involved in FA metabolisms, such as FADS1 and FADS2, and antioxidant status, to obtain a solid and sound knowledge to explain FA accumulation in organic KRC as a representative of slow-growing chickens on OR are needed.

\subsection{Changes in Biochemical Profile and Secondary Protein Structure in Breast Meat}

The average original and second derived SR-FTIR spectra in the fingerprint region of wavenumbers from 3000 to $900 \mathrm{~cm}^{-1}$ obtained from CO and OR are shown in Figure 1A,B, respectively. The difference in the average spectra of breast meat samples from $\mathrm{CO}$ and OR detected in the ranges of $2946 \mathrm{~cm}^{-1}$ and $2885 \mathrm{~cm}^{-1}$ represent lipid; $1700 \mathrm{~cm}^{-1}$ and $1672 \mathrm{~cm}^{-1}$ represent protein (amide I) and 1139 to $955 \mathrm{~cm}^{-1}$ represent carbohydrate and glycogen, respectively.
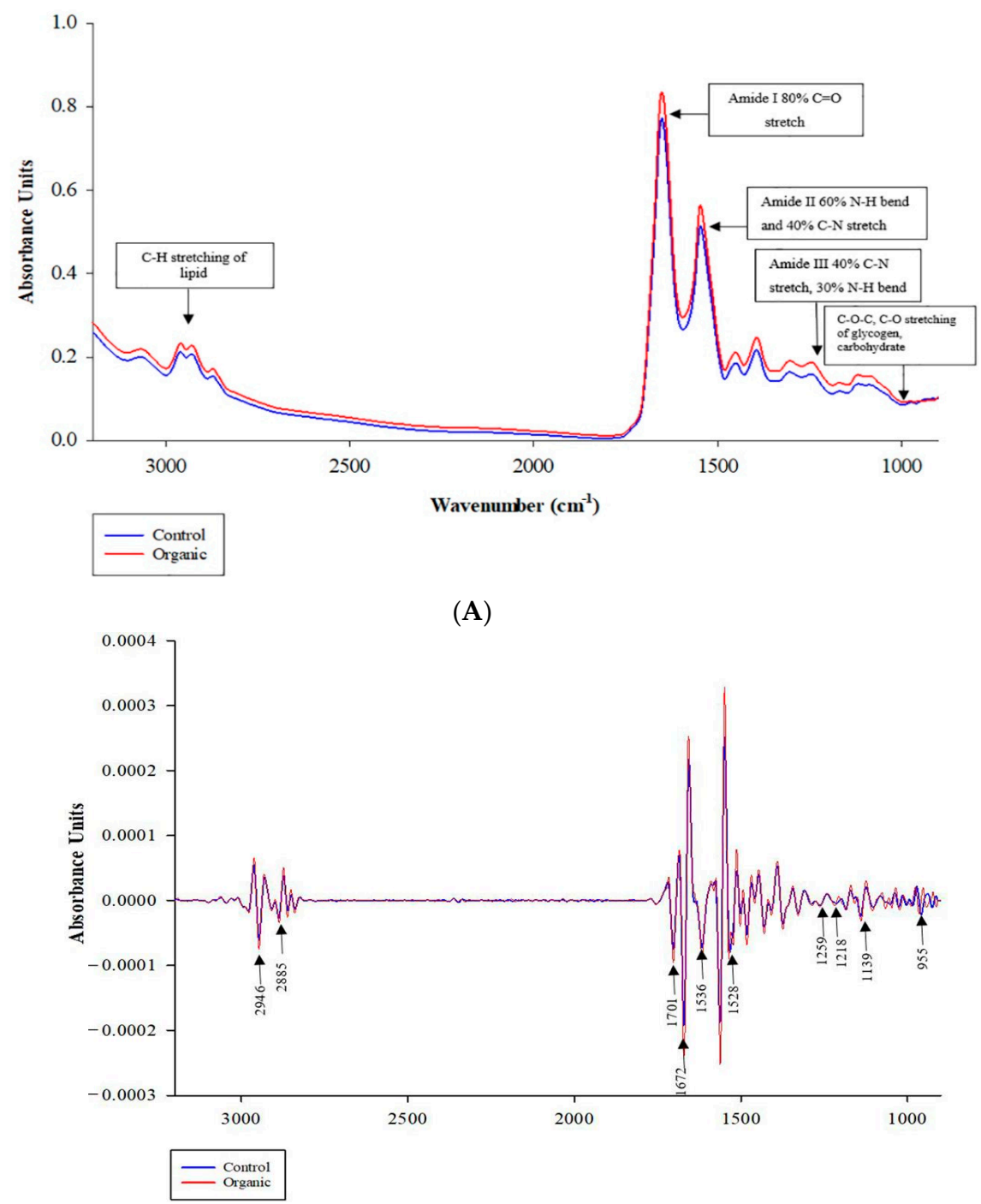

(B)

Figure 1. Average SR-IR spectra of original (A) and second derivative (B) from KRC chicken breast meat between control and organic raising systems. Infrared spectra were collected in the spectral range of 4000 to $900 \mathrm{~cm}^{-1}$, resolution $4 \mathrm{~cm}^{-1}$ based on 300 spectra per treatment. 3000 to $2800 \mathrm{~cm}^{-1}$ (CH stretch of lipid); $1740 \mathrm{~cm}^{-1}$ (C=O ester of lipid); 1700 to $1600 \mathrm{~cm}^{-1}$ (amide I); 1600 to $1500 \mathrm{~cm}^{-1}$ (amide II); $1338 \mathrm{~cm}^{-1}$ (amide III); and 1250 to $900 \mathrm{~cm}^{-1}$ (carbohydrate and glycogen) parameters used for the collected spectra. 
The areas under the peaks in these regions were integrated and calculated, revealing differences in the CO and OR spectra (Table 8). The integral areas of lipid (C-H stretching), amide I ( $\mathrm{C}=\mathrm{O}$ stretching), amide II (C-N stretching vibrations in combination with $\mathrm{N}-\mathrm{H}$ bending), and glycogen regions were greater $(p<0.05)$, whereas no significant difference ( $p=0.061)$ was found in amide III in OR compared to those in CO. On the contrary, the result of amide III obtained from the t-test did not agree with the result of the loading correlation, as shown in Figure 2B. These differences are due to the fact that PCA consists of the analysis of data sets containing imprecise measurements, which only extracts the maximum variance and important information from the data set. It presents the result as a set of summary indicators known as principal components showing the differences in the data matrix [26]. The amide I band represents different types of secondary protein structures such as $\alpha$-helix, $\beta$-sheet, $\beta$-turn, and antiparallel $\beta$-sheet, which are related to meat quality [78]. Here, we examined the secondary structures of proteins in the region of the amide I band, where we found a significant difference and calculated the ratio of their relative contents by curve fitting (Table 9). The results revealed no differences $(p>0.05)$ in secondary protein structure between the OR and CO chickens, except that the $\beta$-sheet of OR chicken meat was slightly lower $(p=0.066)$ than that of $\mathrm{CO}$. A possible reason for this could be that the different fat and FA profile between the two groups could have altered the rate of lipid oxidation leading to different conformational changes in the secondary protein structures [18].

Table 8. The integral area of average spectra of KRC breast meat from different raising systems (mean \pm SD).

\begin{tabular}{cccc}
\hline Biomolecule (Wavenumber) & CO & OR & $p$-Value \\
\hline C-H stretching of lipid & $1.13 \pm 0.005^{\mathrm{a}}$ & $1.10 \pm 0.005^{\mathrm{b}}$ & 0.017 \\
Amide I 80\% C=O stretch & $11.38 \pm 0.007^{\mathrm{b}}$ & $11.97 \pm 0.006^{\mathrm{a}}$ & $<0.0001$ \\
Amide II 60\% N-H bend and 40\% C-N stretch & $0.33 \pm 0.001^{\mathrm{b}}$ & $0.58 \pm 0.001^{\mathrm{a}}$ & $<0.0001$ \\
Amide III 40\% C-N stretch, 30\% N-H bend & $0.74 \pm 0.004$ & $0.78 \pm 0.006$ & 0.061 \\
C-O-C, C-O stretching of glycogen, carbohydrate & $0.29 \pm 0.002^{\mathrm{b}}$ & $0.38 \pm 0.002^{\mathrm{a}}$ & $<0.0001$ \\
\hline
\end{tabular}

$\mathrm{a}, \mathrm{b}$ Means within a row with different superscript letters differ significantly at $p<0.05 . \mathrm{CO}=$ control, $\mathrm{OR}=$ organic raising system.

Table 9. Ratio of relative content of secondary structures determined by SR-IR from KRC organic chickens breast meat.

\begin{tabular}{cccc}
\hline \multirow{2}{*}{ Items } & \multicolumn{2}{c}{$\%$ Curve Fitting \pm SD } & \multirow{2}{*}{$\boldsymbol{p}$-Value } \\
\cline { 2 - 3 } & CO & OR & \\
\hline$\alpha$-helix $\left(1655 \mathrm{~cm}^{-1}\right)$ & $54.40 \pm 5.59$ & $52.23 \pm 5.94$ & 0.163 \\
$\beta$-sheet $\left(1622,1627,1630 \mathrm{~cm}^{-1}\right)$ & $26.77 \pm 2.28$ & $25.44 \pm 2.71$ & 0.066 \\
Antiparallel $\beta$-sheet $\left(1695\right.$ to $\left.1685 \mathrm{~cm}^{-1}\right)$ & $5.25 \pm 6.52$ & $5.08 \pm 7.06$ & 0.918 \\
$\beta$-turn $\left(1670,1678,1680 \mathrm{~cm}^{-1}\right)$ & $18.82 \pm 5.85$ & $22.32 \pm 7.41$ & 0.369 \\
$\alpha$-helix $/ \beta$-sheet & $2.05 \pm 0.28$ & $2.07 \pm 0.26$ & 0.750 \\
\hline
\end{tabular}

$\mathrm{CO}=$ control, $\mathrm{OR}=$ organic raising system.

\subsection{Correlation Loading Plot of FTIR Spectra with the Biochemical Compounds and Quality of Breast Meat from Different Raising Systems}

To elucidate the relationship between biochemical compounds and the quality of breast meat (Figure 2A) from the two raising systems, we combined data from FTIR spectra related to biomolecules and physicochemical properties of chicken meat and then used PCA to classify the $\mathrm{CO}$ and OR groups. As shown in Figure 2A, the meat of chickens from different raising systems was separated, representing $57 \%$ of the total variability of all data sets.

The correlation loading plot in Figure 2B shows traits, shear force, meat color (redness; $a^{*}$, yellowness; $b^{*}$ ), skin color (lightness; $\left.L^{* s}\right)$, CP, lipid, collagen, carbohydrate and glycogen, amide I, amide II of protein, and amide III of collagen located in the outer circle areas, 
which explained over $50 \%$ of the variance between the two groups that had significant correlations among these traits.

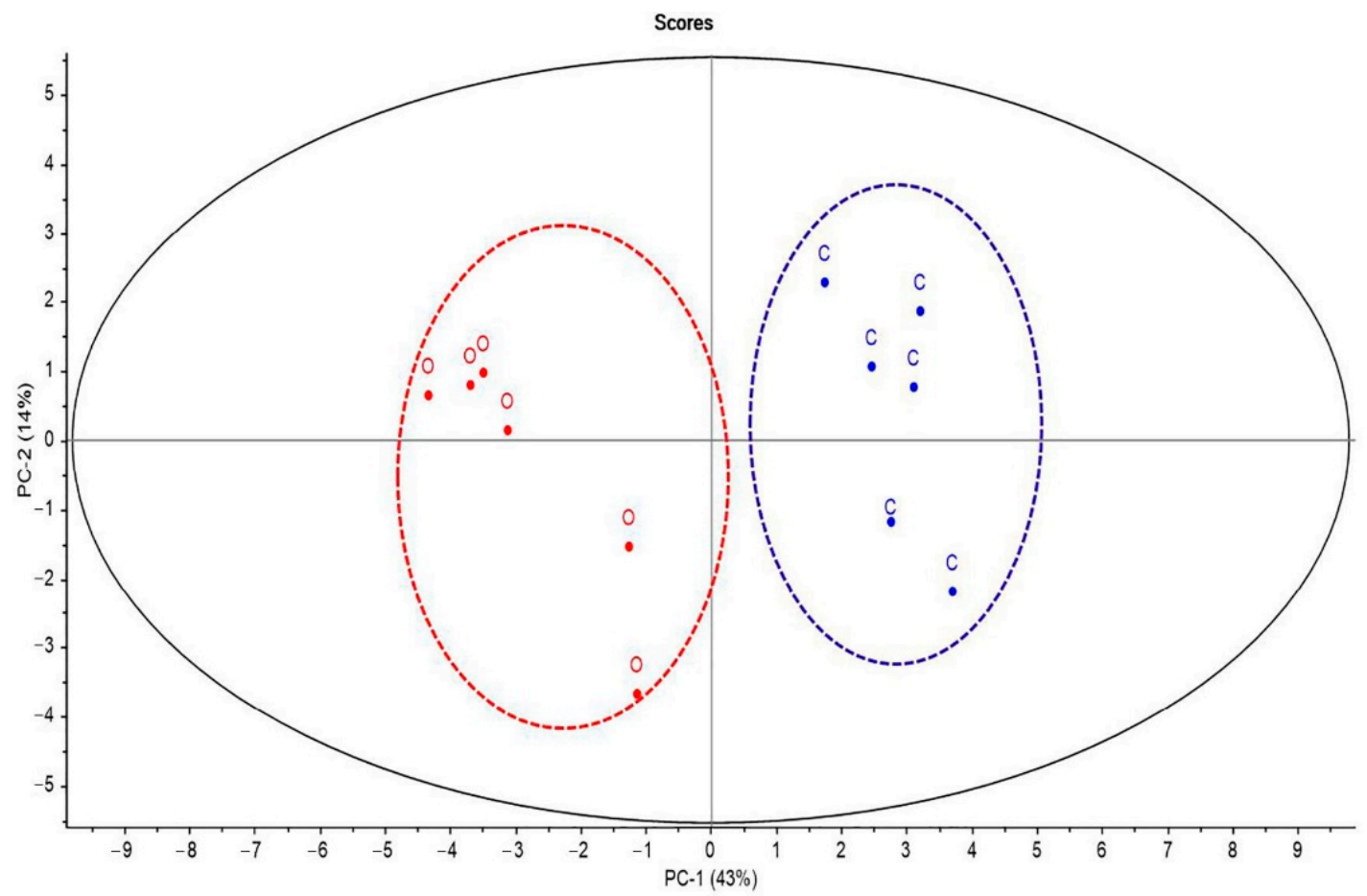

(A)

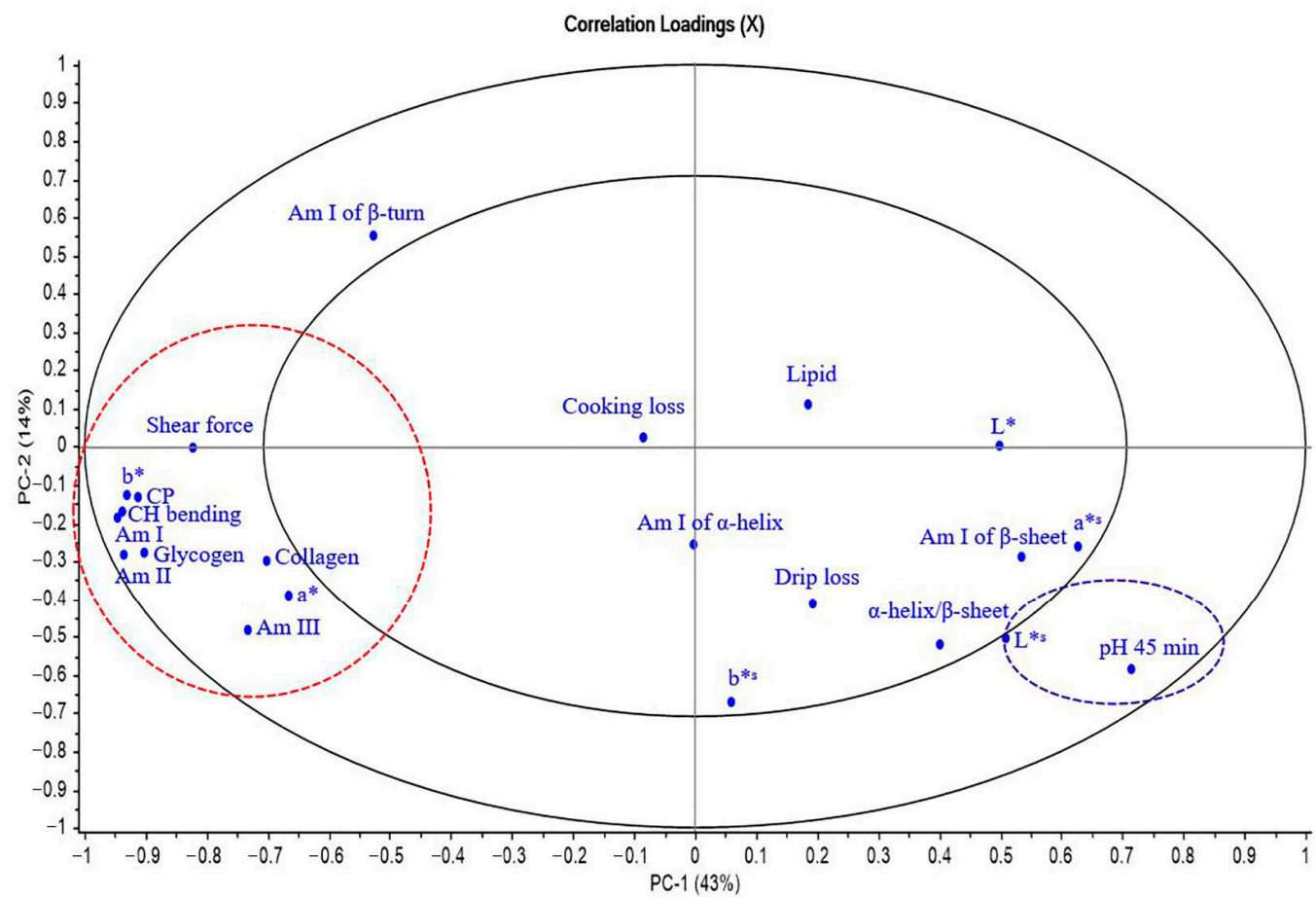

(B)

Figure 2. Cont. 


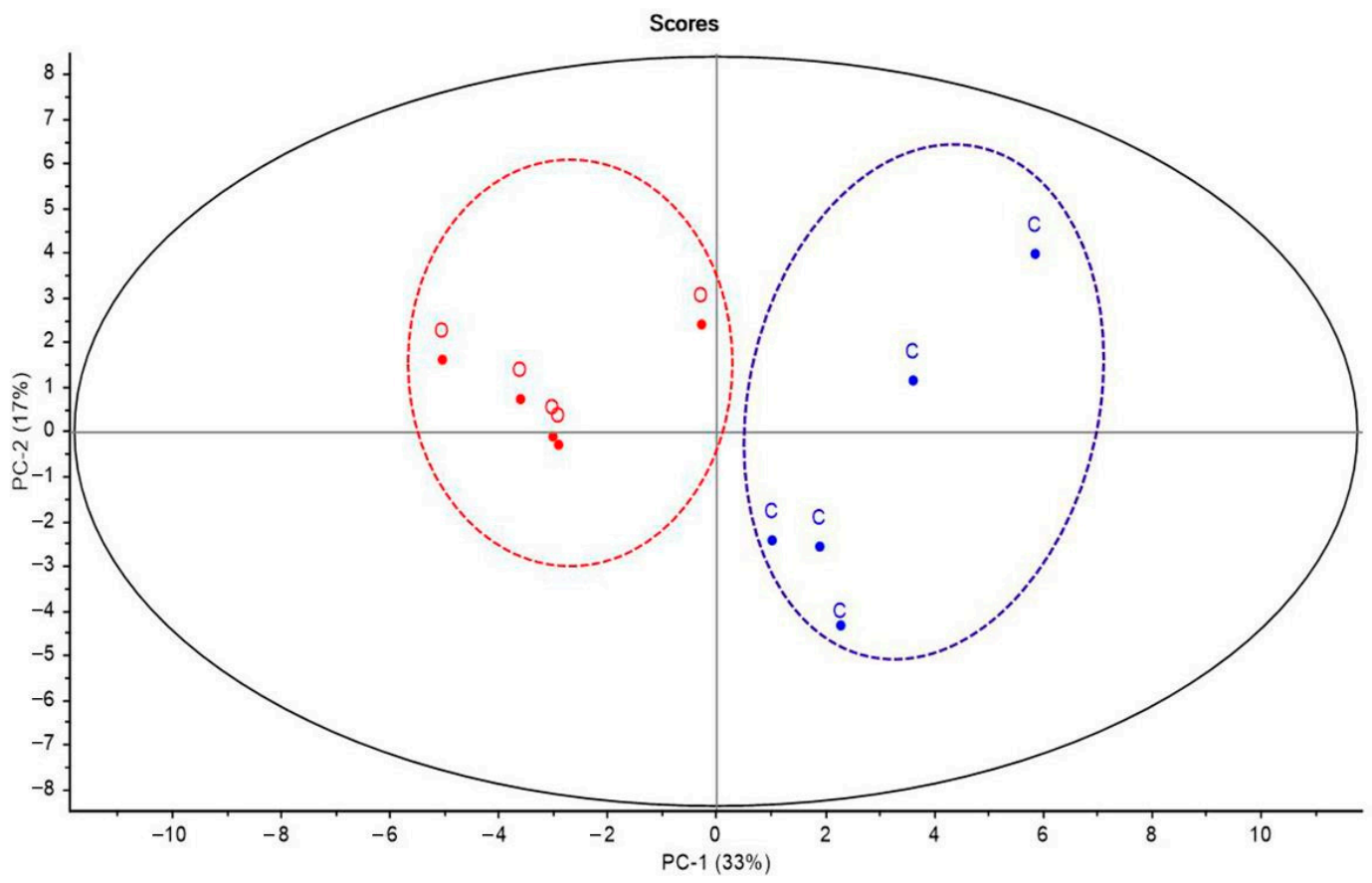

(C)

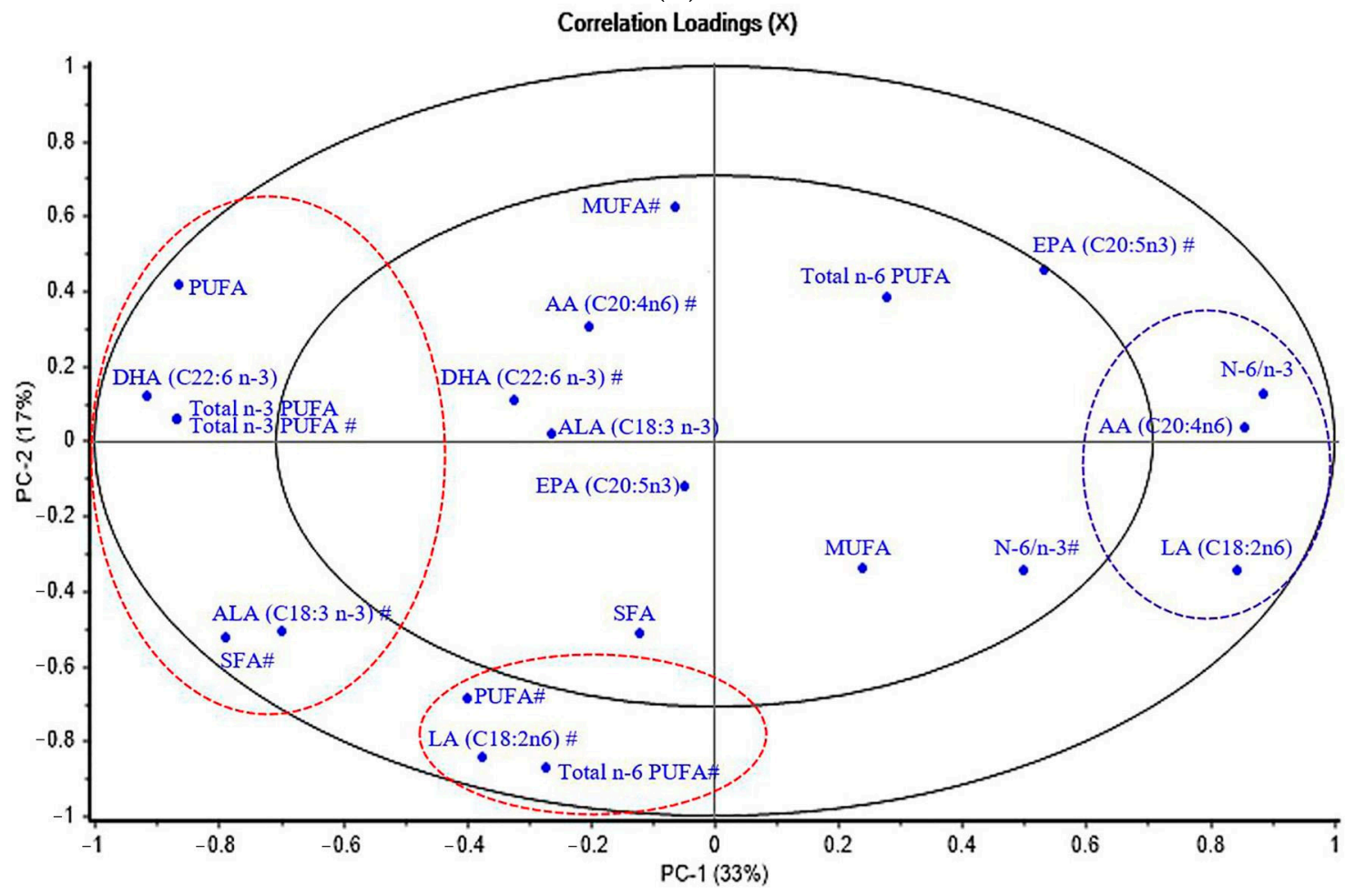

(D)

Figure 2. Principal component analysis (PCA) score plot and correlation loading plot (PC-1 vs PC-2) of SR-FTIR spectra, biochemical compounds and meat quality $(\mathbf{A}, \mathbf{B})$ and fatty acid in breast and thigh meat (C,D) of KRC in different production systems. Abbreviations: C, control group; $\mathrm{O}$, organic group; Am I, amide I of protein; Am II, amide II of protein, Am III, amide III of collagen, $\mathrm{CP}$, crude protein; $\mathrm{a}^{*}$, redness; $\mathrm{b}^{*}$, yellowness; $\mathrm{L}^{*}$, lightness; $\mathrm{a}^{* \mathrm{~s}}$, redness of skin; $b^{* \mathrm{~s}}$, yellowness of skin; $L^{*}$, lightness of skin; SFA, saturated fatty acids; PUFA, polyunsaturated fatty acids; MUFA, monounsaturated fatty acids; $\alpha$-linolenic acid; DHA, docosahexaenoic acid; EPA, eicosapentaenoic acid; LA, linoleic acid; \# = thigh meat, without \# = breast meat. 
The negative loading plot in Figure 2B shows the shear force, meat color ( $\mathrm{a}^{*}$ and $\left.\mathrm{b}^{*}\right)$, $\mathrm{CP}$, collagen content, amide I of protein $\left(1700\right.$ to $\left.1600 \mathrm{~cm}^{-1}\right)$, amide II of protein (1480 to $1575 \mathrm{~cm}^{-1}$ ), amide III of collagen (1229 to $1310 \mathrm{~cm}^{-1}$ ), carbohydrate and glycogen (1200 to $1000 \mathrm{~cm}^{-1}$ ), and lipid (2955 to $2800 \mathrm{~cm}^{-1}$ ) were positively correlated with negative score plot from chicken breast meat in the OR group. Although the amide I of $\beta$-turn (1670 to $1680 \mathrm{~cm}^{-1}$ ) was in the outer circle, its position was close to the PC-2 axis of the loading plot, meaning that they could not be used to distinguish breast meat from $\mathrm{CO}$ and OR. On the contrary, the positive loading plot showed that skin color (lightness; $\mathrm{L}^{* \mathrm{~S}}$ ) was positively correlated with the positive score plot of chicken breast meat from $\mathrm{CO}$. The results revealed that the raising system could differentiate meat properties.

The PCA results confirmed the results shown in Tables 4 and 5. In addition, glycogen and lipids identified by SR-FTIR were higher in the breast meat of OR chicken than those in $\mathrm{CO}$ chicken. This could be explained by the fact that organic chickens have high activity and more glycogen storage in their skeletal muscle [79].

Furthermore, under excess glycogen stores, glucose can be converted to fat, which is stored in the muscle by de novo lipid synthesis [80]. Therefore, we analyzed the relationship between raising systems and FA composition in chicken meat using PCA. As shown in Figure $2 \mathrm{C}$, the FA profiles in chicken breast and thigh meat from different raising systems were separated with $50 \%$ of the total variability of all data sets. The correlation loading plot in Figure 2D shows the traits, total SFA, PUFA, linoleic acid (LA; C18:2n-6), arachidonic acid (C20:4n-6; AA), and n-3 PUFAs such as ALA and DHA located in the outer circle areas, which explained over $50 \%$ of the variance between the two groups that had significant correlations among these traits.

The negative loading plot in Figure 2D shows that PUFA, n-3 PUFA in the breast and thigh, ALA, SFA, and LA in thigh and DHA in breast meat were positively correlated with the negative score plot from chicken meat in the OR group. The positive loading plot in Figure 2D shows that the ratio of n- 6 to n-3 PUFA was positively correlated with the positive loading plot of $\mathrm{CO}$ but negatively correlated with the negative score plot of chicken meat from OR.

The PCA results confirmed some FA components in chicken meat from the OR, as shown in Table 7. Moreover, the PCA result explored the correlation between OR and amount of SFA in thigh meat, which could be attributed to the FA composition of the feed, especially Ruzi grass that contains $22.91 \%$ SFA. In addition, the analysis revealed higher contents of PUFA and ALA and a lower content of n-6 PUFA in OR. These results further supported the conclusion that feed plays an important role in modifying the FA profile of chicken meat. Furthermore, it has been shown that high amounts of PUFA and ALA in Ruzi grass can modify PUFA and ALA in meat, while an increased intake of PUFA, especially FA from the n-3 PUFA group, can reduce n-6 PUFA such as LA in breast and AA in thigh meat [81].

\section{Conclusions}

In conclusion, our results reveal that OR has no negative effect on the growth performance of slow-growing chickens. The study shows that the OR system has a positive effect on the meat characteristics, especially meat color and texture, biochemical compounds such as proteins (amide I and amide II), total collagen (amide III), and beneficial FA (PUFA, DHA, and ALA), which determine the nutritional value of meat. The findings of this study demonstrate the potential of OR for commercial adoption in tropical regions such as Southeast Asia. Furthermore, the study demonstrates the efficiency of SR-FTIR to determine the differences in the biochemical compounds, which could serve as markers to monitor meat quality traits. Collectively, these findings provide insights into the relative roles of raising systems in KRC chickens and can help producers to produce nutritionally rich quality products while maintaining animal welfare standards. 
Author Contributions: Conceptualization, W.M. and A.M.; methodology, W.M. and A.M.; investigation, W.M., W.K. and P.T.; formal analysis, W.M., W.K., P.T. and K.T.; writing-original draft preparation, W.M., W.K. and A.M.; writing-review and editing, W.M., W.K., K.T. and A.M.; supervision, J.Y.; project administration, W.M.; funding acquisition, W.M. and A.M. All authors have read and agreed to the published version of the manuscript.

Funding: This work was supported by the Suranaree University of Technology (SUT), the Thailand Science Research and Innovation (TSRI), and the National Science, Research and Innovation Fund (NSRF) (project code 90464). We also thank the National Research Council of Thailand (NRCT) (project code SUT3-303-59-12-24), and the Center of Excellence on Technology and Innovation for Korat Chicken Business Development which was granted by SUT (project code CoE3-303-62-60-02) for their financial support.

Institutional Review Board Statement: The experiments were conducted with appropriate management to ensure that unnecessary discomfort to the animals was avoided. The Ethics Committee on Animal Use of the Suranaree University of Technology (SUT), Nakhon Ratchasima, Thailand, approved all the procedures used in this present experiment (user application ID: U1-02633-2559).

Data Availability Statement: The data presented in this study are available on request from the corresponding author.

Acknowledgments: We thank Beamline 4.1, Infrared Spectroscopy and Imaging (Synchrotron Light Research Institute, Public Organization), Nakhon Ratchasima, Thailand, for kindly assisting with part of the statistical data and sample analysis using SR-FTIR. We also thank Suranaree University of Technology for the Full-time Master Researcher grant (Grant ID: Full-time61/25/2562).

Conflicts of Interest: The authors declare no conflict of interest.

\section{References}

1. Srednicka-Tober, D.; Baranski, M.; Seal, C.; Sanderson, R.; Benbrook, C.; Steinshamn, H.; Gromadzka-Ostrowska, J. Composition differences between organic and conventional meat: A systematic literature review and meta-analysis. Br. J. Nutr. 2016, 115, 994-1011. [CrossRef] [PubMed]

2. Dalle Zotte, A.; Gleeson, E.; Franco, D.; Cullere, M.; Lorenzo, J.M. Proximate composition, amino acid profile, and oxidative stability of slow-growing indigenous chickens compared with commercial broiler chickens. Foods 2020, 9, 546. [CrossRef] [PubMed]

3. Abbas, T.E.; Ahmed, M.E. Poultry meat quality and welfare as affected by organic production system. AVS 2015, 3, 1-4. [CrossRef]

4. Miao, Z.H.; Glatz, P.C.; Ru, Y.J. Free-range poultry production-A review. Asian-Australas. J. Anim. Sci. 2005, 18, 113-132.

5. Grashorn, M.A.; Serini, C.T. Quality of chicken meat from conventional and organic production. Proc. EPC 2006, 10-14.

6. Husak, R.L.; Sebranek, J.G.; Bregendahl, K. A survey of commercially available broilers marketed as organic, free-range, and conventional broilers for cooked meat yields, meat composition, and relative value. Poult. Sci. 2008, 87, 2367-2376. [CrossRef]

7. Kucheruk, M.; Midyk, S.; Zasekin, D.; Ushkalov, V.; Kepple, O. Comparison of fatty acid content of organic and traditionally grown broiler chickens. Food Sci. Technol. 2019, 13, 51-57. [CrossRef]

8. Hovi, M.; Sundrum, A.; Thamsborg, S.M. Animal health and welfare in organic livestock production in Europe: Current state and future challenges. Livest. Prod. Sci. 2003, 80,41-53. [CrossRef]

9. Comert, M.; Sayan, Y.; Kırkpınar, F.; Bayraktar, O.H.; Mert, S. Comparison of carcass characteristics, meat quality, and blood parameters of slow and fast grown female broiler chickens raised in organic or conventional production system. Asian-Australas. J. Anim. Sci. 2016, 29, 987-997. [CrossRef]

10. Dal Bosco, A.; Mattioli, S.; Cartoni Mancinelli, A.; Cotozzolo, E.; Castellini, C. Extensive rearing systems in poultry production: The right chicken for the right farming system. A review of twenty years of scientific research in Perugia University, Italy. Animals 2021, 11, 1281. [CrossRef]

11. Kubota, S.; Vandee, A.; Keawnakient, P.; Molee, W.; Yongsawatdikul, J.; Molee, A. Effects of the MC4R, CAPN1, and ADSL genes on body weight and purine content in slow-growing chickens. Poult. Sci. 2019, 98, 4327-4337. [CrossRef] [PubMed]

12. Castellini, C.; Mugnai, C.; Dal Bosco, A. Effect of organic production system on broiler carcass and meat quality. Meat Sci. 2002, 60, 219-225. [CrossRef]

13. Castellini, C.; Mugnai, C.; Dal Bosco, A. Meat quality of three chicken genotypes reared according to the organic system. Ital. J. Food Saf. 2002, 14, 401-412.

14. Galvez, F.; Dominguez, R.; Maggiolino, R.A.; Pateiro, K.; Carballo, M.; Lorenzo, J.M. Meat quality of commercial chickens reared in different production systems: Industrial, range and organic. Ann. Anim. Sci. 2020, 20, 263-285. [CrossRef]

15. Sogut, B.; Inci, H.; Sengul, T. Growth performance and carcass traits of broiler reared in conventional and organic conditions. Asian J. Anim. Vet. Adv. 2011, 6, 992-1000. [CrossRef] 
16. Kucukyilmaz, K.; Bozkurt, M.; Catli, A.U.; Herken, E.N.; Cinar, M.; Bintas, E. Chemical composition, fatty acid profile and colour of broiler meat as affected by organic and conventional rearing systems. S. Afr. J. Anim. Sci. 2012, 42, 361-368. [CrossRef]

17. Jiang, S.; Jiang, Z.; Lin, Y.; Zhou, G.; Chen, F.; Zheng, C. Effects of different rearing and feeding methods on meat quality and antioxidative properties in Chinese Yellow male broilers. Br. Poult. Sci. 2011, 52, 352-358. [CrossRef]

18. Spickett, C.M.; Pitt, A.R. Modification of proteins by reactive lipid oxidation products and biochemical effects of lipoxidation. Essays Biochem. 2020, 64, 19-31. [CrossRef]

19. Yang, Y.; Wen, J.; Fang, G.Y.; Li, Z.R.; Dong, Z.Y. The effects of raising system on the lipid metabolism and meat quality traits of slow-growing chickens. J. Appl. Anim. Res. 2015, 43, 147-152. [CrossRef]

20. Li, Y.; Luo, C.; Wang, J.; Guo, F. Effects of different raising systems on growth performance, carcass, and meat quality of medium-growing chickens. J. Appl. Anim. Res. 2017, 45, 326-330. [CrossRef]

21. Mato, A.; Rodriguez Vazquez, R.; Lopez Pedrouso, M.D.; Bravo Lopez, M.D.; Franco Ruiz, S.B.; Zapata Babio, J.C. The first evidence of global meat phosphoproteome changes in response to pre-slaughter stress. BMC 2019, 20, 590-605. [CrossRef]

22. Baker, M.J.; Trevisan, J.; Bassan, P.; Bhargava, R.; Butler, H.J.; Dorling, K.M.; Fielden, P.R.; Fogarty, S.W.; Fullwood, N.J.; Heys, K.A.; et al. Using Fourier transform IR spectroscopy to analyze biological materials. Nat. Protoc. 2014, 9, 1771-1791. [CrossRef] [PubMed]

23. Diem, M.; Meo, M.; Atthaus, C.; Miljkovic, M.; Miller, L.; Lasch, P. Comparison of fourier transform infrared (FTIR) spectra of individual cells acquired using synchrotron and conventional sources. Infrared Phys. Technol. 2004, 45, 331-338. [CrossRef]

24. Chen, Y.; Zou, C.; Mastalerz, M.; Hu, S.; Gasaway, C.; Tao, X. Applications of micro-Fourier transform infrared spectroscopy (FTIR) in the geological sciences-a review. Int. J. Mol. Sci. 2015, 16, 30223-30250. [CrossRef]

25. Holman, H.Y.N.; Martin, M.C.; Mckinney, W.R. Tracking chemical changes in a live cell: Biomedical applications of SR-FTIR spectromicroscopy. Spectroscopy 2003, 17, 139-159. [CrossRef]

26. Poompramun, C.W.; Thumanu, M.K.; Molee, A. The significant influence of Residual Feed Intake (RFI) on flavor precursors and biomolecules in slow-growing Korat chicken meat. Anim. Biosci. 2021, 34, 1684-1694. [CrossRef]

27. National Bureau of Agricultural Commodity and Food Standards. Thai Agricultural Standard Tas 9000 Part 2-2018, 2nd ed.; ACFS Press: Bangkok, Thailand, 2018.

28. Wattanachant, S.; Benjakul, S.; Ledward, D.A. Composition, color, and texture of Thai indigenous and broiler chicken muscles. Poult. Sci. 2004, 83, 123-128. [CrossRef] [PubMed]

29. Zhang, R.P.; Liu, H.H.; Li, Q.Q.; Wang, Y.; Liu, J.Y.; Hu, J.W.; Yan, X.P.; Gou, H.; Li, L.; Wang, J.W. Gene expression patterns, and protein metabolic and histological analyses for muscle development in Peking duck. Poult. Sci. 2014, 93, 3104-3111. [CrossRef] [PubMed]

30. Association of Official Analytical Chemists (AOAC). Official Methods of Analysis of AOAC, 18th ed.; Association of Official Analytical Chemists: Washington, DC, USA, 2010.

31. Jeon, H.J.; Choe, J.H.; Jung, Y.K.; Kruk, Z.A.; Lim, D.G.; Jo, C.R. Comparison of the chemical composition, textural characteristics, and sensory properties of north and south Korean native chickens and commercial broilers. Food Sci. Anim. Resour. 2010, 30, 171-178. [CrossRef]

32. Folch, J.; Lees, M.; Sloane Stanley, G.H. A simple method for the isolation and purification of total lipids from animal tissues. J. Biol. Chem. 1957, 226, 497-509. [CrossRef]

33. Metcalfe, L.D.; Schmitz, A.A.; Pelka, J.R. Rapid preparation of fatty acid esters from lipids for gas chromatographic analysis. Anal. Chem. 1966, 38, 514-519. [CrossRef]

34. Da Silva, C.M.L.; Spinelli, E.; Rodrigues, S.V. Fast and sensitive collagen quantification by alkaline hydrolysis/hydroxyproline assay. Food Chem. 2015, 173, 619-623. [CrossRef] [PubMed]

35. Bergman, I.; Loxley, R. Two improved and simplified methods for the spectrophotometric determination of hydroxyproline. Anal. Chem. 1963, 35, 1961-1965. [CrossRef]

36. Kim, Y.B.; Ku, S.K.; Joo, B.J.; Lee, N.H.; Jang, A. Changs in nucleotide compounds, and chemical and sensory qualities of duck meat during aging at $0{ }^{\circ} \mathrm{C}$. Korean J. Food Sci. Anim. Resour. 2012, 32, 428-433. [CrossRef]

37. Rowea, A.; Macedob, F.A.F.; Visentainer, J.V.; Souzaa, N.E.; Matsushita, M. Muscle composition and fatty acid profile in lambs fattened in drylot or pasture. Meat Sci. 1999, 51, 283-288. [CrossRef]

38. Helm, D.; Labischinski, H.; Schallehn, G.; Naumann, D. Classification and identification of bacteria by Fourier-transform infrared spectroscopy. Microbiology 1991, 137, 69-79. [CrossRef]

39. Liyanage, S.; Dassanayake, R.S.; Bouyanfif, A.; Rajakaruna, E.; Ramalingam, L.; Moustaid-Moussa, N.; Abidi, N. Optimization and validation of cryostat temperature conditions for trans-reflectance mode FTIR microspectroscopic imaging of biological tissues. MethodsX 2017, 4, 118-127. [CrossRef]

40. Candogan, K.E.; Altuntas, G.; Igci, N. Authentication and quality assessment of meat products by Fourier-transform infrared (FTIR) spectroscopy. Food Eng. Rev. 2020, 13, 66-91. [CrossRef]

41. Wilkosz, N.; Czaja, M.; Seweryn, S.; Skirlinska-Nosek, K.; Szymonski, M.; Lipiec, E.; Sofinska, K. Molecular spectroscopic markers of abnormal protein aggregation. Molecules 2020, 25, 2498. [CrossRef]

42. Barth, A. Infrared spectroscopy of proteins. Biochim. Biophys. Acta (BBA)-Bioenerg. 2007, 1767, 1073-1101. [CrossRef]

43. Davis, R.; Mauer, L.J. Fourier transform infrared (FT-IR) spectroscopy: A rapid tool for detection and analysis of foodborne pathogenic bacteria. Appl. Microbiol. Biotechnol. 2010, 2, 1582-1594. 
44. Guo, X.J.; Wang, R.Q. Changes in secondary structure of myofibrillar protein and its relationship with water dynamic changes during storage of battered and deep-fried pork slices. Food Sci. Biotechnol. 2018, 27, 1667-1673. [CrossRef] [PubMed]

45. Wasagu, R.S.U.; Abubakar, M.K.; Lawal, M.; Njoku, C.H. Secondary Structures associated with alkaline transition of horse heart ferricytochrome c: An FTIR study. Nig. J. Basic Appl. Sci. 2010, 18, 249-259. [CrossRef]

46. Mattioli, S.; Cartoni Mancinelli, A.; Menchetti, L.; Dal Bosco, A.; Angelucci, E.; Castellini, C. How the kinetic behavior of organic chickens affects productive performance and blood and meat oxidative status: A study of six poultry genotypes. Poult. Sci. 2021, 100, 101297. [CrossRef]

47. Adedeji, O.S.; Amao, S.R.; Oyewumi, S.O.; Alimi, D.H. Growth performance of organically raised broiler chickens at 8 weeks age. Int. J. Appl. Sci. 2014, 3, 140-147.

48. Santos, A.L.; Sakomura, N.K.; Freitas, E.R.; Fortes, C.M.S.; Carrilho, E.N.M. Comparison of free range broiler chicken strains raised in confined or semi-confined systems. Braz. J. Poult. Sci. 2005, 7, 85-92. [CrossRef]

49. Wan, J.H.; Zhang, R.; Gong, A.H.; Gong, D.Q. Effects of different feeding methods on the growth performance of Liyang chicken. China Poult. 2011, 33, 57-58.

50. Li, L.; Wang, H.H.; Liu, S.Z.; Li, Y.X. Effects of different feeding methods on the production performance and fat deposition of Tibet chicken. Anim. Husb. Feed Sci. 2011, 32, 2-3.

51. Liu, Z.Y. Effects of different feeding methods on the growth, slaughter performance and meat quality of Guinea fowl. J. Anhui Agric. Univ. 2012, 40, 13397-13417.

52. Stolze, M.; Piorr, A.; Haring, A.M.; Dabbert, S. Environmental Impacts of Organic Farming in Europe; Haring, A., Ed.; Pages 23-86 in impact of organic farming on the environment and resource use; Universität Hohenheim, Stuttgart-Hohenheim: Ettlingen, Germany, 2000.

53. Tufarelli, V.; Ragni, M.; Laudadio, V. Feeding forage in poultry: A promising alternative for the future of production systems. Agriculture 2018, 8, 81. [CrossRef]

54. Rothrock, M.J.; Locatelli, A. Importance of farm environment to shape poultry-related microbiomes throughout the farm-to-fork continuum of pasture-raised broiler flocks. Front. Sustain. Food Syst. 2019, 3, 48. [CrossRef]

55. Fanatico, A.C.; Pillai, P.B.; Emmert, J.L.; Owens, C.M. Meat quality of slow-and fast-growing chicken genotypes fed low-nutrient or standard diets and raised indoors or with outdoor access. Poult. Sci. 2007, 86, 2245-2255. [CrossRef] [PubMed]

56. Holcman, A.R.; Žlender, V.B.; Stibilj, V. Chemical composition of chicken meat from free-range and extensive indoor rearing. Arch Geflügelk. 2003, 67, 120-124.

57. Katemala, S.; Molee, A.; Thumanu, K.; Yongsawatdigul, J. Meat quality and Raman spectroscopic characterization of Korat hybrid chicken obtained from various rearing periods. Poult. Sci. 2021, 100, 1248-1261. [CrossRef] [PubMed]

58. Zhang, T.; Lu, H.; Wang, L.; Yin, M.; Yang, L. Specific expression pattern of IMP metabolism related-genes in chicken muscle between cage and free range conditions. PLoS ONE 2018, 13, e0201736. [CrossRef]

59. Wilson, D.F.; Matschinsky, F.M. Metabolic homeostasis: Oxidative phosphorylation and the metabolic requirements of higher plants and animals. J. Appl. Physiol. 2018, 125, 1183-1192. [CrossRef]

60. Peifer, S.; Barduhn, T.; Zimmet, S.; Volmer, D.A.; Heinzle, E.; Schneider, K. Metabolic engineering of the purine biosynthetic pathway in Corynebacterium glutamicum results in increased intracellular pool sizes of IMP and hypoxanthine. Microb. Cell Factories 2012, 11. [CrossRef]

61. Miller, B.F.; Olesen, J.L.; Hansen, M.; Dossing, S.; Crameri, R.M.; Welling, R.J.; Langberg, H.; Flyvbjerg, A.; Kjaer, M.; Babraj, J.A.; et al. Coordinated collagen and muscle protein synthesis in human patella tendon and quadriceps muscle after exercise. $J$. Physiol. 2005, 567, 1021-1033. [CrossRef]

62. Mikulski, D.; Celej, J.; Jankowski, J.; Majewska, T.; Mikulska, M. Growth performance, carcass traits and meat quality of slowergrowing and fast-growing chickens raised with and without outdoor access. Asian-Australas. J. Anim. Sci. 2011, 24, 1407-1416. [CrossRef]

63. Tumova, E.; Teimouri, A. Chicken muscle fibres characteristics and meat quality. A Review. Sci. Agric. Bohem. 2009, 40, $253-258$.

64. Scheffler, T.L.; Park, S.; Gerrard, D.E. Lessons to learn about postmortem metabolism using the AMPK $\gamma 3$ R200Q mutation in the pig. Meat Sci. 2011, 89, 244-250. [CrossRef] [PubMed]

65. Kim, T.W.; Kim, C.W.; Yang, M.R.; No, G.R.; Kim, S.W.; Kim, I.S. Pork quality traits according to postmortem $\mathrm{pH}$ and temperature in berkshire. Korean J. Food Sci. An. 2016, 36, 29-36. [CrossRef] [PubMed]

66. Bowker, B.; Zhuang, H. Relationship between water-holding capacity and protein denaturation in broiler breast meat. Poult. Sci. 2015, 94, 1657-1664. [CrossRef] [PubMed]

67. Cavitt, L.C.; Youm, G.W.; Meullenet, J.F.; Owens, C.M.; Xiong, R. Prediction of poultry meat tenderness using Razor Blade Shear, Allo-Kramer Shear and Sarcomere Length. J. Food Sci. 2004, 69, 11-15. [CrossRef]

68. Vestergaard, M.; Oksbjerg, N.; Henckel, P. Influence of feeding intensity, grazing and finishing feeding on muscle fibre characteristics and meat colour of semitendinosus, longissimus dorsi and supraspinatus muscles of young bulls. Meat Sci. 2000, 54, 177-185. [CrossRef]

69. Van Wessel, T.; de Haan, A.; van der Laarse, W.J.; Jaspers, R.T. The muscle fiber type-fiber size paradox: Hypertrophy or oxidative metabolism? Eur. J. Appl. Physiol. 2010, 110, 665-694. [CrossRef]

70. Poltowicz, K.; Doktor, J. Effect of free-range raising on performance, carcass attributes and meat quality of broiler chicken. Anim. Sci. Pap. Rep. 2011, 29, 139-149. 
71. Komprda, T.; Zelenka, J.; Tieffova, P.; Stohandlova, M.; Foltyn, J. Effect of the growth intensity on cholesterol and fatty acids content in broiler chicken tissues. Arch. Fur Geflugelkd. 1999, 63, 36-43.

72. Dewhurst, R.J.; Nigel, S. Forages, fat, fitness and flavour. Iger Innov. 1998, 2, 36-39.

73. Boschetti, E.; Bordoni, A.; Meluzzi, A.; Castellini, C.; Dal Bosco, A.; Sirri, F. Fatty acid composition of chicken breast meat is dependent on genotype-related variation of FADS1 and FADS2 gene expression and desaturating activity. Animal 2016, 10, 700-708. [CrossRef]

74. Bou, R.; Guardiola, F.; Tres, A.; Barroeta, A.; Codony, R. Effect of dietary fish oil, $\alpha$-tocopheryl acetate, and zinc supplementation on the composition and consumer acceptability of chicken meat. Poult. Sci. 2004, 83, 282-292. [CrossRef]

75. Cortinas, L.; Villaverde, C.; Galobart, J.; Baucells, M.D.; Codony, R.; Barroeta, A.C. Fatty acid content in chicken thigh and breast as affected by dietary polyunsaturation level. Poult. Sci. 2004, 83, 1155-1164. [CrossRef]

76. Lopez-Ferrer, S.; Baucells, M.; Barroeta, A.; Grashorn, M. n-3 enrichment of chicken meat. 1. Use of very long-chain fatty acids in chicken diets and their influence on meat quality: Fish oil. Poult. Sci. 2001, 80, 741-752. [CrossRef] [PubMed]

77. Griffin, B.A. How relevant is the ratio of dietary n-6 to n-3 polyunsaturated fatty acids to cardiovascular disease risk? Evidence from the OPTILIP study. Curr. Opin. Lipidol. 2008, 19, 57-62. [CrossRef] [PubMed]

78. Silva-Buzanello, R.A.; Schuch, A.F.; Gasparin, A.W.; Torquato, A.S.; Scremin, F.R.; Canan, C.; Soares, A.L. Quality parameters of chicken breast meat affected by carcass scalding conditions. Asian-Australas. J. Anim. Sci. 2019, 32, 1186-1194. [CrossRef] [PubMed]

79. Nakatani, A.; Han, D.H.; Hansen, P.A.; Nolte, L.A.; Host, H.H.; Hickner, R.C.; Holloszy, J.O. Effect of endurance exercise training on muscle glycogen supercompensation in rats. J. Appl. Physiol. 1997, 82, 711-715. [CrossRef] [PubMed]

80. Jensen, J.; Rustad, P.I.; Kolnes, A.J.; Lai, Y.C. The role of skeletal muscle glycogen breakdown for regulation of insulin sensitivity by exercise. Front. Physiol. 2011, 2, 112. [CrossRef] [PubMed]

81. Simopoulos, A.P. Omega-6/omega-3 essential fatty acid ratio and chronic diseases. Food Rev. Int. 2004, 20, 77-90. [CrossRef] 